\title{
KEYLINK: towards a more integrative soil representation for inclusion in ecosystem scale models. II. Model description, implementation and testing
}

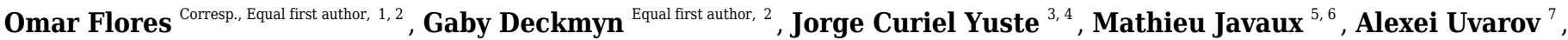 \\ Sietse van der Linde ${ }^{8}$, Bruno De Vos ${ }^{9}$, Harry Vereecken ${ }^{6}$, Juan Jiménez ${ }^{10}$, Olga Vinduskova $^{2}$, Andrea Schnepf ${ }^{6}$ \\ ${ }^{1}$ Biogeography and Global Change, National Museum of Natural Sciences, Consejo Superior de Investigaciones Científicas, Madrid, Spain \\ 2 PLECO, Department of Biology, Universiteit Antwerpen, Antwerp, Belgium \\ 3 BC3 - Basque Centre for Climate Change, Leioa, Spain \\ 4 IKERBASQUE - Basque Foundation for Science, Bilbao, Spain \\ 5 Earth and Life Institute, Université Catholique de Louvain, Louvain-la-Neuve, Belgium \\ 6 Agrosphere Institute (IBG-3), Forschungszentrum Jülich GmbH, Jülich, Germany \\ 7 Laboratory of Soil Zoology, A.N. Severtsov Institute of Ecology and Evolution, Russian Academy of Sciences, Moscow, Russia \\ 8 Forest Research, Farnham, United Kingdom \\ 9 Department of Environment and Climate, Research Institute for Nature and Forest, Brussels, Belgium \\ 10 Instituto Pirenaico de Ecología, Consejo Superior de Investigaciones Científicas, Jaca, Spain \\ Corresponding Author: Omar Flores \\ Email address: omar.flores@uantwerpen.be
}

New knowledge on soil structure highlights its importance for hydrology and soil organic matter (SOM) stabilization, which however remains neglected in many wide used models. We present here a new model, KEYLINK, in which soil structure is integrated with the existing concepts on SOM pools, and elements from food web models, i.e. those from direct trophic interactions among soil organisms. KEYLINK is, therefore, an attempt to integrate soil functional diversity and food webs in predictions of soil carbon (C) and soil water balances. We present a selection of equations that can be used for most models as well as basic parameter intervals for, e.g., key pools, functional groups' biomasses and growth rates. Parameter distributions can be determined with Bayesian calibration, and here an example is presented for food web growth rate parameters for a pine forest in Belgium. We show how these added equations can improve the functioning of the model in describing known phenomena. For this, five test cases are given as simulation examples: changing the input litter quality (recalcitrance and carbon to nitrogen ratio), excluding predators, increasing $\mathrm{pH}$ and changing initial soil porosity. These results overall show how KEYLINK is able to simulate the known effects of these parameters and can simulate the linked effects of biopore formation, hydrology and aggregation on soil functioning. Furthermore, the results show an important trophic cascade effect of predation on the complete $\mathrm{C}$ cycle with repercussions on the soil structure as ecosystem engineers are Peerj reviewing PDF | (2020:03:47320:2:0:NEW 17 Nov 2020) 
predated, and on SOM turnover when predation on fungivore and bacterivore populations are reduced. In summary, KEYLINK shows how soil functional diversity and trophic organization and their role in $\mathrm{C}$ and water cycling in soils should be considered in order to improve our predictions on $\mathrm{C}$ sequestration and $\mathrm{C}$ emissions from soils. 
1 KEYLINK: towards a more integrative soil representation for

2 inclusion in ecosystem scale models. II. Model description,

3 implementation and testing.

4

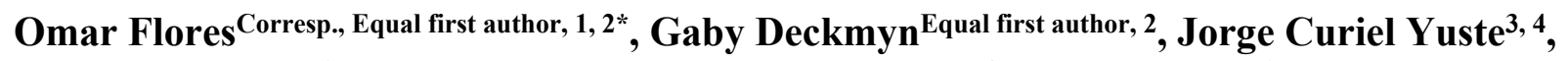
Mathieu Javaux $^{5,6}$, Alexei Uvarov ${ }^{7}$, Sietse van der Linde ${ }^{8}$, Bruno De Vos ${ }^{9}$, Harry Vereecken $^{6}$, Juan Jiménez ${ }^{10}$, Olga Vinduskova ${ }^{2}$, Andrea Schnepf ${ }^{6}$

${ }^{1}$ Department of Biogeography and Global Change, National Museum of Natural Sciences Spanish National Research Council (MNCN-CSIC), Madrid, Spain

${ }^{2}$ Centre of Excellence PLECO, Department of Biology, Universiteit Antwerpen, Antwerp, Belgium

${ }^{3}$ BC3-Basque Centre for Climate Change, Leioa, Spain

${ }^{4}$ IKERBASQUE - Basque Foundation for Science, Bilbao, Spain

${ }^{5}$ Earth and Life Institute, Université Catholique de Louvain, Louvain-la-Neuve, Belgium

${ }^{6}$ Agrosphere Institute (IBG-3), Forschungszentrum Jülich GmbH, Jülich, Germany

${ }^{7}$ Laboratory of Soil Zoology, A.N. Severtsov Institute of Ecology and Evolution, Russian Academy of Sciences, Moscow, Russia

${ }^{8}$ Forest Research, Farnham, United Kingdom

${ }^{9}$ Department of Environment and Climate, Research Institute for Nature and Forest, Brussels, Belgium

${ }^{10}$ ARAID, Pyrenean Institute of Ecology - Spanish National Research Council (IPE-CSIC), Jaca, Spain

\section{Corresponding Author:}

Omar Flores ${ }^{1,2}$

Universiteitsplein 1, Wilrijk, 2610, Belgium

Email address: dr.flores.omar@gmail.com

\section{Abstract}

New knowledge on soil structure highlights its importance for hydrology and soil organic matter (SOM) stabilization, which however remains neglected in many wide used models. We present here a new model, KEYLINK, in which soil structure is integrated with the existing concepts on 
SOM pools, and elements from food web models, i.e. those from direct trophic interactions among soil organisms. KEYLINK is, therefore, an attempt to integrate soil functional diversity and food webs in predictions of soil carbon (C) and soil water balances. We present a selection of equations that can be used for most models as well as basic parameter intervals for, e.g., key pools, functional groups' biomasses and growth rates. Parameter distributions can be determined with Bayesian calibration, and here an example is presented for food web growth rate parameters for a pine forest in Belgium. We show how these added equations can improve the functioning of the model in describing known phenomena. For this, five test cases are given as simulation examples: changing the input litter quality (recalcitrance and carbon to nitrogen ratio), excluding predators, increasing $\mathrm{pH}$ and changing initial soil porosity. These results overall show how KEYLINK is able to simulate the known effects of these parameters and can simulate the linked effects of biopore formation, hydrology and aggregation on soil functioning. Furthermore, the results show an important trophic cascade effect of predation on the complete $\mathrm{C}$ cycle with repercussions on the soil structure as ecosystem engineers are predated, and on SOM turnover when predation on fungivore and bacterivore populations are reduced. In summary, KEYLINK shows how soil functional diversity and trophic organization and their role in $\mathrm{C}$ and water cycling in soils should be considered in order to improve our predictions on $\mathrm{C}$ sequestration and $\mathrm{C}$ emissions from soils.

\section{Introduction}

Soil models used in ecosystem-scale modelling need to be relatively simple and fast at performing calculations. Nonetheless, carbon (C) and nutrient turnover and hydrology are extremely important for determining ecosystem productivity and $C$ sequestration in the ecosystem. The most widely used soil models (Century, RothC) emphasize the $\mathrm{C}$ flow from easily degradable to stable organic compounds using first-order kinetics to describe their decay rates (Campbell and Paustian, 2015). The relevance of chemical recalcitrance, used in those models, is accepted in the early stages of litter decomposition, but that approach has been questioned on the long term soil organic matter (SOM) stabilization (Schmidt et al., 2011), highlighting the relevance of other processes in the physical protection of SOM within soil matrix (Deckmyn et al., 2020). This has led to the development of models including an explicit representation of structural effects on SOM (Kuka et al., 2007). Furthermore, recent studies have shown that microbial products from the transformation of plant litter are the largest contributors to stable SOM (Mambelli et al., 2011; Cotrufo et al., 2013).

The insights concerning the role of the microbial biomass in $\mathrm{C}$ turnover has been introduced in models such as MIcrobial-MIneral Carbon Stabilization (MIMICS) model (Wieder et al., 2014; Wieder et al., 2015) and Litter Decomposition and Leaching (LIDEL) model (Campbell et al., 2016). However, soil fauna and especially ecosystem engineers, i.e. organisms that create, modify or maintain habitats by changing the physical structure of the ecosystem (Jones et al., 1994), have also been shown to play a key role in determining $C$ and nutrient turnover and hydrology of soils through their impact on aggregation, pore formation and bioturbation as well as their direct contribution to litter and SOM turnover (Filser et al., 2016; Lavelle et al., 2016). Several authors have highlighted the need to include soil fauna contributions to SOM dynamics into soil modelling (see review by Vereecken et al., 2016). This information has been used in detailed and small-scale soil models (Chertov et al., 2017a; Geisen et al., 2019), but is not 
incorporated into larger-scale ecosystem models. The main difficulty is the lack of data concerning the soil, either physical, chemical or biological, and the different methods used, making parameterization of any model unsure. The goal of the KEYLINK model is to consider the soil including the main mechanisms concerning the effects of soil biota on litter and SOM transformations and hydrology through structural modifications, without increasing the number of parameters beyond what is currently available on most well-measured ecosystems (Deckmyn et al., 2020). We show how this model has been parameterized for a forest stand where soil fauna was never studied in detail, but many other soil and stand characteristics are well established.

The core model concept is the strong link between soil biota, soil structure and turnover (Fig. 1). The decay of fresh litter is dependent on the recalcitrance and carbon to nitrogen $(\mathrm{N})$ ratio $(\mathrm{C}: \mathrm{N})$ of the litter, although different soil biota groups have specific sensibilities to recalcitrance and $\mathrm{C}: \mathrm{N}$ ratio. For $\mathrm{SOM}$, the turnover depends on the accessibility, linked to the pore size distribution, the aeration and $\mathrm{H}_{2} \mathrm{O}$ in the pores and the aggregation (based on the model by Kuka, Franko and Rühlmann, 2007). Both SOM and litter turnover depend on temperature and humidity. Soil fauna, specifically ecosystem engineers, directly affect pore distribution besides an important effect on bioturbation. Pore distribution affects hydrology which again affects all soil processes.

The scientific background for the model is fully described in Deckmyn et al. (2020). Here, the related processes are formulated mathematically. Finally, we show how the model can simulate several known mechanisms of soil faunal effects such as changes in litter recalcitrance affecting fungal/bacterial ratio, changes in $\mathrm{pH}$ affecting earthworm populations, effects of ecosystem engineers on bioturbation and hydrology, and importance of microbivores and predators in the soil fauna food web.

\section{Methodology}

The KEYLINK model has been conceptually designed integrating the structure of the soil by its porosity, the hydrology and the $\mathrm{C}$ cycle through the soil food web. Those key parts of the soil interact (Fig. 1) determining the rates of SOM stabilization and $\mathrm{CO}_{2}$ emissions from soil. The functions developed to represent and simulate those processes are presented here.

\section{$\underline{\text { Structural effects }}$}

Pore size distribution determines accessibility for trophic interactions of soil fauna and soil microorganisms (Fig. 2), both by size and by aeration and $\mathrm{H}_{2} \mathrm{O}$; soil fauna changes pore size distribution and produces cracks and fissures in the soil. In the model, pore size distribution is divided into the following five categories:

- Inaccessible pores $(<0.1 \mu \mathrm{m}$ in diameter): pores around inaccessible $\mathrm{C}$ (within the micro-aggregate, organo-clay interaction). Water is held here but is not available to plants (measured from wilting point). The volume of inaccessible pores is related to the clay content and type.

- Bacterial pores $(0.1-2 \mu \mathrm{m})$ : the pores within macro-aggregates and pores in loam, accessible only to bacteria. Engineer saprotrophs (e.g. earthworms) can also use SOM in these pores (and in the following pore categories, all except inaccessible pores) because they eat directly all soil. 
141

142

143

144

145

146

147

148

149

150

151

152

153

154

155

156

157

158

- Micropores $(2-30 \mu \mathrm{m})$ : pores not accessible to macrofauna, mesofauna and most predators, but accessible to microfauna bacterivores and fungivores, fungi, mycorrhiza and bacteria. Water is held at field capacity but available to plants. In sandy soil and within macro-aggregates $(>250 \mu \mathrm{m})$, pores fall in this category.

- Mesopores $(30 \mu \mathrm{m}-1.5 \mathrm{~mm})$ : pores where most soil fauna can penetrate (not macrofauna) between large macro-aggregates $(>1 \mathrm{~mm})$ or formed by fine roots. Mesopore volume can be determined in the field from drained water capacity (but this includes macropores). These pores are well aerated also at field capacity, but can dry out below field capacity.

- Macropores $(>1.5 \mathrm{~mm})$ : cracks or biopores formed by ecosystem engineers. They are of vital importance for soil hydrology as preferential flow through these pores has a major impact on infiltration rate. These are the first pores to have $\mathrm{O}_{2}$ when water level is above field capacity, but dry out quickly below field capacity.

The initial values of soil porosity in the model simulations can be calculated from measured soil water retention curves, or even using models such as Saxton et al. (1986) that yield field capacity, porosity and wilting point from the $\mathrm{C}$, clay and sand contents, or using measured bulk density $\left(\mathrm{D}_{\mathrm{b}}\right)$. Following Malamoud et al. (2009), the percentage of total porosity $\left(\mathrm{P}_{\%}\right)$ can be computed from $D_{b}$ and soil particle density $\left(D_{S}\right)$ as shown in equation 2 . $D_{S}$ can be measured or is calculated from $\mathrm{D}_{\mathrm{m}}=$ soil mineral particle density $\left(2.65 \mathrm{~g} \mathrm{~cm}^{-3}\right)$ and $\mathrm{D}_{\mathrm{SOM}}=$ organic particle density $\left(1.35 \mathrm{~g} \mathrm{~cm}^{-3}\right)$ as:

$D_{\mathrm{S}}=\frac{100}{\frac{\% \text { SOM }}{D_{\text {SOM }}}+\frac{100-\% \text { SOM }}{D_{\mathrm{m}}}}$

$P_{\%}=\frac{D_{s}-D_{b}}{D_{s}} 100$

\section{$\underline{\text { Water flow }}$}

We advise using KEYLINK model in combination with a detailed water model including preferential flow through macropores as well as good representation for matrix flow (s.a. Richards' equation). However, we show in this paper how it can be used with a simpler representation of water flow but still allowing the important dynamic interactions between pore sizes and hydrology that are fundamental to the model. A spilling bucket approach is used at a daily time-step, where water drains from a layer into the underlying layer when its water content is above field capacity in the soil matrix. However, in contrast to conventional spilling bucket models, we allow water to flow faster through macropores (before the soil matrix is saturated). Net precipitation $\left(\mathrm{P}_{\text {net }}\right)$ is calculated as:

$\mathrm{P}_{\text {net }}=\mathrm{P}-\mathrm{E}$

where $\mathrm{P}$ is precipitation $\left(\mathrm{mm} \mathrm{day}^{-1}\right)$ and $\mathrm{E}$ is evapotranspiration $\left(\mathrm{mm} \mathrm{day}^{-1}\right)$ from measured or modelled data (vegetation model). Infiltration (I) is assumed to be equal to the part of precipitation entering the soil. Infiltration and runoff $\left(\mathrm{P}_{\text {runoff, }} \mathrm{mm}_{\text {day }}{ }^{-1}\right)$ must equal $\mathrm{P}_{\text {net }}$. 
159

160

161

162

163

164

165

166

167

168

169

170

171

172

173

174

175

176

177

178

179

180

181

182

183

184

185

186

187

188

189

190

191

192

193

194

195

$\mathrm{I}+\mathrm{P}_{\text {runoff }}=\mathrm{P}_{\text {net }}$

Infiltration is composed of water entering the soil matrix, water filling the macropores and water draining from macropores. Water that enters macropores remains in the macropore domain or enters the layers below. The fraction of infiltration entering macropores depends on the surface area of the macropores $\left(\mathrm{SA}_{\text {macro }}\right)$, assumed cylindrical. Assume measured or derived maximal infiltration rate $\left(\mathrm{I}_{\text {maxMat }}, \mathrm{mm}\right.$ day $\left.^{-1}\right)$ of the soil matrix. Maximal infiltration rate through macropores $\left(\mathrm{I}_{\text {maxPor}}, \mathrm{mm}\right.$ day $\left.^{-1}\right)$ is calculated from the volume of the pores $\left(\mathrm{PV}_{\text {macro }}\right)$, assumed not limiting at daily scale, plus infiltration capacity of the layer $(n+1)$ in which the macropores end.

$\mathrm{I}_{\text {maxPor }}=\mathrm{PV}_{\text {macro }}+\mathrm{I}_{\operatorname{maxMat}(\mathrm{n}+1)}$

If $\mathrm{P}_{\text {net }}>\left(\mathrm{I}_{\operatorname{maxPor}}+\mathrm{I}_{\text {maxMat }}\right)$ runoff is calculated as:

$\mathrm{P}_{\text {runoff }}=\mathrm{P}_{\text {net }}-\left(\mathrm{I}_{\text {maxPor }}+\mathrm{I}_{\text {maxMat }}\right)$

after which calculations continue using $\mathrm{P}_{\text {net }}-\mathrm{P}_{\text {runoff }}$ as net precipitation.

If $\mathrm{I}_{\text {maxMat }}<\mathrm{P}_{\text {net }}<\left(\mathrm{I}_{\text {maxPor }}+\mathrm{I}_{\text {maxMat }}\right)$ the soil matrix is filled at a rate equal to the maximum infiltration rate, all other water is lost either through the macropores to the next layer or by filling macropores. If $\mathrm{I}_{\text {maxMat }}>\mathrm{P}_{\text {net }}$ the soil matrix is filled with water, traditional spilling bucket, but an equivalent volume is lost through macropores to the bottom layer depending on the surface area of the macropores. The total soil water volume of soil layer $\mathrm{n}, \mathrm{SW}_{\mathrm{n}}$, is then limited by the total pore volume of the layer and the water already filling the pores, and is calculated as:

$\mathrm{SW}_{\mathrm{n}}=\mathrm{SW}_{\mathrm{n}}+\min \left(\mathrm{PV}_{\mathrm{n}}-\mathrm{SW}_{\mathrm{n}}, \mathrm{I}_{\text {maxmat }}\left(1-\mathrm{SA}_{\text {macro }}\right), \operatorname{Pnet}\left(1-\mathrm{SA}_{\text {macro }}\right)\right)$

For drainage (D) to the bottom layer, the spilling bucket approach is used plus a portion of water that goes straight through the macropores, calculated from the surface area of the macropores.

$\mathrm{D}_{\mathrm{n}}=\mathrm{P}_{\text {net }} \mathrm{SA}_{\text {macro }}+\mathrm{P}_{\text {net }}-$

$\min \left(\mathrm{PV}_{\mathrm{n}}-\mathrm{SW}_{\mathrm{n}}, \mathrm{I}_{\text {maxmat }}\left(1-\mathrm{SA}_{\text {macro }}\right), \mathrm{P}_{\text {net }}\left(1-\mathrm{SA}_{\text {macro }}\right)\right)$

For each pore size class the fraction water filled is calculated from the water content: so always one pore size is partially saturated and all others are either saturated or dry within one layer.

\section{$\underline{\text { C flow }}$}

The KEYLINK model combines soil organic matter modelling with soil food web modelling. The model conceptualized in Figure 2 has 13 carbon pools (Table S1.2 in Supplemental File S1), visualised by boxes. Above and belowground litter is assumed to be provided from an external source (tree shoot in Figure 2) not covered by this model. It could be given through experimental data or an external model, e.g., a tree growth model that delivers the input of litter into the litter pool. All simulations presented here were made with constant C inputs (Table S2.6 in Supplemental File S2). Exudation is an input of organic carbon released from roots into the soil organic matter pool. Every live pool has a respiration rate (r) and a turnover or death rate (d). On consuming a $\mathrm{C}$ pool, a fraction of this pool always becomes faeces and enters the SOM pool except for the microbial pools, i.e. microbes and microbivores. SOM can be distributed in 
196

197

198

199

200

201

202

203

204

205

206

207

208

209

210

211

212

213

214

215

216

217

218

219

220

221

222

223

224

225

226

227

228

229

230

231

232

233

234

different fractions, particulate organic matter (POM) and dissolved organic matter (DOM), which can gain relevance in the addition and simulation of other nutrient cycles and processes as leaching. However, here, as a first version of the model, we present a simplification using SOM as a uniform pool. The growth $\left(\mathrm{G}, \mathrm{g} \mathrm{C} \mathrm{m}^{-3} \mathrm{day}^{-1}\right)$ of a biomass pool $\left(\mathrm{B}, \mathrm{g} \mathrm{C} \mathrm{m}^{-3}\right)$ is described according to Monod kinetic,

$\mathrm{G}=\sum_{n=1}^{N}\left(\mathrm{~g}_{\max }\left(\frac{\mathrm{Sf}_{\mathrm{a}}}{\mathrm{K}_{\mathrm{s}}+\mathrm{S}}\right)_{\mathrm{n}}\right) \mathrm{B}$

where $\mathrm{g}_{\max }\left(\mathrm{g} \mathrm{C} \mathrm{g} \mathrm{C}^{-1}\right.$ day $\left.^{-1}\right)$ is the maximal rate of growth, to which several modifiers are applied (see descriptions below). Substrate $\left(\mathrm{S}, \mathrm{g} \mathrm{C} \mathrm{m}^{-3}\right)$ is the consumable pool, litter, SOM or biomass of soil organism (n), that consumer pool (B) can use but corrected by its available fraction $\left(\mathrm{f}_{\mathrm{a}}\right)$. All fluxes $(\mathrm{N})$ of consumed $\mathrm{C}$ from each $\mathrm{S}$ are summed. $\mathrm{K}_{\mathrm{s}}\left(\mathrm{g} \mathrm{C} \mathrm{m}^{-3}\right)$ is related to substrate quality, it gives the content required to get half the maximal growth. This is not related to the amount that will be consumed, because consumed $\mathrm{C}$ equals growth + faeces, but shows how dense the material needs to be 'found' by the consumer. Available fraction of a S to a consumer (as $\mathrm{f}_{\mathrm{a}}$ ) is calculated using the fraction from total porosity volume that is accessible for the consumer, by size, minus its fraction that is completely flooded or dry (see equations 14-16). This availability introduces the concept of physical recalcitrance, highlighting the role that soil structure plays affecting $\mathrm{C}$ fluxes in the soil, because SOM decomposition rates modelling use to rely on its chemical recalcitrance, from now on referred just as 'recalcitrance'. But physical recalcitrance has proven to be also relevant for the calculation of SOM decomposition rates (von Lützow et al., 2008), and soil matrix also affect other biotic interactions through the food web by this availability concept.

Rate of increase of a population of meso- or macrofauna depends on generation time (r, K strategies), age distribution of the population, different life stages. Models exist for only some soil fauna species (Osler and Sommerkorn, 2007; Chertov et al. 2017a). To offer a solution that can work for both the microbial biomass and the meso- and macrofauna, we use $g_{\max }$ as equal to the maximal rate of increase in biomass of any population, $\mathrm{dB} / \mathrm{dt}=\mathrm{g}_{\max }$ when resources are nonlimiting and assuming the population structure is stable and optimal, equal to what is often stated as the intrinsic growth rate of a species (Birch, 1948).

The net rate of change of a biomass pool is the sum of growth $(\mathrm{G})$, respiration $(\mathrm{R})$ and turnover (death, $\mathrm{D}_{\mathrm{t}}$ ), and possibly predation $\left(\mathrm{P}_{\mathrm{d}}\right)$, all in $\mathrm{g} \mathrm{C} \mathrm{m}^{-3}$ day $^{-1}$ :

$\frac{\mathrm{dB}}{\mathrm{dt}}=\mathrm{G}-\mathrm{R}-\mathrm{D}_{\mathrm{t}}-\mathrm{P}_{\mathrm{d}}$

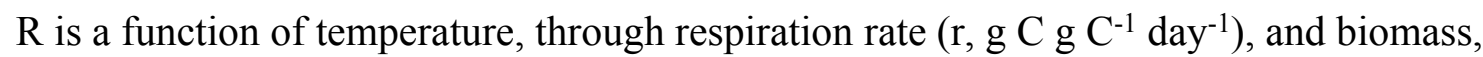
assuming the same temperature sensitivity as growth; this is somewhat different to how it is seen in many models where a food source is turned over with a specific efficiency. From a more faunal point of view, this makes sense: a food source is 'consumed'; the consumed material is partly excreted and partly assimilated and spent on respiration and growth (i.e. biomass formation).

$\mathrm{R}=\mathrm{rB}$

While the death rate $\mathrm{d}\left(\mathrm{g} \mathrm{C} \mathrm{g} \mathrm{C}^{-1}\right.$ day $\left.^{-1}\right)$ is constant. 
236 Predation depends on biomass of predator or microbivore and is calculated from the growth of the predator $\left(\mathrm{G}_{\text {pred }}\right.$, from equation 9$)$ plus the fraction of the prey allocated to faeces $\left(f_{\text {faec }}\right)$.

238

$\mathrm{P}_{\mathrm{d}_{\text {prey }}}=\mathrm{G}_{\text {pred }}\left(1+\mathrm{f}_{\text {faec }}\right)$

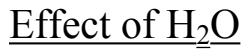

241

242

243

Drought or saturation of a pore leads to reduced availability of the $\mathrm{C}$ in the pore for its food web consumers. First, the overall effect of hydration is calculated as a modifier $\left(\mathrm{m}_{\mathrm{H} 2 \mathrm{Otot}}\right)$ in function of volumetric soil moisture $(\mathrm{V})$ and pore volume $\left(\mathrm{P}_{\mathrm{vol}}\right)$ (after Freytag and Luttich, 1985).

$$
\mathrm{m}_{\text {H2Otot }}= \begin{cases}4 \frac{\mathrm{V}}{\mathrm{P}_{\mathrm{vol}}}\left(1-\frac{\mathrm{V}}{\mathrm{P}_{\mathrm{vol}}}\right) & \text { for } \frac{\mathrm{V}}{\mathrm{P}_{\mathrm{vol}}}<0.5 \\ 1 & \text { for } \frac{\mathrm{V}}{\mathrm{P}_{\mathrm{vol}}}>0.5\end{cases}
$$

250

251

252

253

254

255

256

257

258

259

260

261

262

263

264

265

266

267

The activity is always in the pores that are not water-logged, therefore the pore size class that is partially filled with water, and the pore size above that is assumed not yet completely dry (after Kuka, Franko and Rühlmann, 2007).

$\mathrm{m}_{\mathrm{H} 2 \mathrm{O}}=\frac{\mathrm{P}_{\mathrm{volA}}}{\mathrm{P}_{\mathrm{volA}}+\mathrm{P}_{\mathrm{volW}}} \mathrm{m}_{\mathrm{H} 2 \mathrm{Otot}}$ for the pores partially filled,

$\mathrm{m}_{\mathrm{H} 2 \mathrm{O}}=\frac{\mathrm{P}_{\mathrm{volW}}}{\mathrm{P}_{\mathrm{volA}}+\mathrm{P}_{\mathrm{volW}}} \mathrm{m}_{\mathrm{H} 2 \mathrm{Otot}}$ for the pores one class above,

where $\mathrm{P}_{\text {volw }}$ is the water filled pore volume and $\mathrm{P}_{\text {volA }}$ is the aerated pore volume. The availability $\left(f_{a}\right)$ of a substrate to a consumer is defined by the inherent availability of the pore size to the consumer, multiplied with $\mathrm{m}_{\mathrm{H} 2 \mathrm{O}}$. For surface litter these calculations are not possible since the surface litter is not in the soil matrix. However, on days without precipitation, litter humidity is assumed to be related to the soil humidity below, therefore the $\mathrm{m}_{\mathrm{H} 2 \mathrm{O}}$ calculated for the microbial biomass is used.

\section{Simulating the variability in $g_{\max }$}

The maximum growth of biota is influenced by different environmental factors. Each one can lead to a modifier $(\mathrm{m} \in[0,1])$ on $\mathrm{g}_{\max }$. It is easy to change, add or turn off specific modifiers according to the soil studied. Here we present a modelling framework focused on abiotic controls of growth rates, but there is room for new add-ons as for example death rate modifiers as a density-dependent microbial turnover. While interaction processes affected by the demographic density of microbial communities (e.g. competition, space constraints) can play also a significant role controlling growth and decomposition rates and improve its modelling (Georgiou et al., 2017), our aim in this work is to link the key roles of fauna and soil structure in C cycle modelling, and together with the hydrology can simulate constraints in biotic interactions, which are also relevant controls in microbial growth and activity. 
Simulating the effect of temperature (T)

270

271

272

273

274

275

276

277

278

279

280

281

282

283

284

285

286

287

288

289

290

291

292

293

294

295

296

297

To simulate the effect of $\mathrm{T}$ on growth rate through a temperature modifier $\left(\mathrm{m}_{\mathrm{T}}\right)$, we use a Q10shaped curve between maximum tolerable temperature $\left(\mathrm{T}_{\max }\right)$ and minimum temperature for consumers activity $\left(\mathrm{T}_{\min }\right)$, set as a default at $0^{\circ} \mathrm{C}$ (Franko, 1989), but unlike many models, we assume a plateau above the optimal temperature $\left(\mathrm{T}_{\mathrm{opt}}\right)$.

$\mathrm{m}_{\mathrm{T}}=\left\{\begin{array}{ccc}0, & & \mathrm{~T}<\mathrm{T}_{\min } \text { or } \mathrm{T} \geq \mathrm{T}_{\max } \\ \mathrm{Q}^{\left(\mathrm{T}-\mathrm{T}_{\text {opt }}\right) / 10}, \mathrm{~T}_{\min } \leq & \mathrm{T}<\mathrm{T}_{\text {opt }} \\ 1, & \mathrm{~T}_{\text {opt }} \leq & \mathrm{T}<\mathrm{T}_{\max }\end{array}\right.$

However, temperature also increases respiration $(\mathrm{R})$. To simulate this temperature effect, we assume the same Q10 function but without the plateau; in this way, when $\mathrm{T}$ is above the optimum, $\mathrm{R}$ increases while growth does not. At some point these lines will cross and cause a net reduction in biomass.

\section{Effect of $\mathrm{pH}$ on growth}

A good example of an optional effect is the effect of $\mathrm{pH}$ : for a system close to a threshold, simulating $\mathrm{pH}$ can be very important, assuming a good knowledge of the system. But for wellbuffered systems, it is an unnecessary increase in complexity. $\mathrm{g}_{\max }$ decreases at low $\mathrm{pH}$ for bacteria but increases for fungi (Rousk, Brookes and Bååth, 2009; Rousk et al., 2010; Rousk, Brookes and Bååth, 2010). For this example, we put the thresholds at 8 for fungi and 3 for bacteria, with precision of one decimal, inducing a 10 fold reduction in $\mathrm{g}_{\max }$ for a change in $\mathrm{pH}$ of 1 .

$\mathrm{m}_{\mathrm{pH}}=1 /((\mathrm{pH}-8) 10) \quad$ for fungi if $\mathrm{pH} \geq 8.1$

$\mathrm{m}_{\mathrm{pH}}=1 /((3-\mathrm{pH}) 10) \quad$ for bacteria if $\mathrm{pH} \leq 2.9$

In any other case for bacteria or fungi, $\mathrm{m}_{\mathrm{pH}}=1$, and if $\mathrm{m}_{\mathrm{pH}}$ goes above 1 , it is replaced by 1 . For engineer saprotrophs, their optimal $g_{\max }$ changes (becoming $g_{\max E n g}$ ) with $\mathrm{pH}$ (Lavelle, Chauvel and Fragoso, 1995; Chertov et al., 2017b) according to the following equation:

$g_{\text {maxEng }}=\left\{\begin{array}{cc}0, & \text { if } p H<3 \\ \left(\frac{g_{\max }}{2}\right)(\mathrm{pH}-3), & \text { if } 3 \leq \mathrm{pH}<5 \\ \mathrm{~g}_{\text {max }} & \text { if } \mathrm{pH} \geq 5\end{array}\right.$

\section{Effect of recalcitrance and C:N on $\mathrm{g}_{\max }$}

Overall consumption of an organism that can consume different pools is computed by simply adding them up. However, litter is not necessarily as 'palatable', depending on its $\mathrm{C}: \mathrm{N}$ ratio if 
298

299

300

301

302

303

304

305

306

307

308

309

310

311

312

313

314

315

316

317

318

319

320

321

322

323

324

325

326

327

328

329

330

331

332

333

not enough $\mathrm{N}$, and on recalcitrance if low in energy, then it is needed to consume more litter, which is calculated through modifiers $\mathrm{m}_{\mathrm{C}: \mathrm{N}}$ and $\mathrm{m}_{\mathrm{rec}}$, respectively. This is simulated by changing $g_{\max }$. The equation for $m_{\text {rec }}$ is not necessary and only important if enough data on litter quality is available or the users are interested into looking into the effects of changes in litter quality. The litter pool can be consumed by both bacteria and fungi, and of course also detritivores.

Depending on the $\mathrm{C}: \mathrm{N}$ ratio, the competition between these two is different; this is simulated by the $\mathrm{g}_{\max }$ of the bacteria being more variable with $\mathrm{C}: \mathrm{N}$ ratio. The sensitivity is described by the parameter $\mathrm{p}_{\mathrm{mC}: \mathrm{N}}$, between 0 and 1 .

$$
\begin{aligned}
& \text { fungi: } \mathrm{m}_{\mathrm{C}: \mathrm{N}_{\text {fung }}}=\min \left(1,\left(\frac{\mathrm{C}: \mathrm{N}_{\text {fung }}}{\mathrm{C}: \mathrm{N}_{\text {lit }}}\right)^{\mathrm{p}}{ }_{\mathrm{mC}: \mathrm{Nfung}}\right) \\
& \text { bacteria: } \mathrm{m}_{\mathrm{C}: \mathrm{N}_{\text {bact }}}=\min \left(1,\left(\frac{\mathrm{C}: \mathrm{N}_{\text {bact }}}{\mathrm{C}: \mathrm{N}_{\text {lit }}}\right)^{\mathrm{p}_{\mathrm{mC}: \text { Nbact }}}\right)
\end{aligned}
$$

For litter recalcitrance $\left(\operatorname{Rec}_{\text {lit }}\right)$, a linear equation instead of a power is chosen so that decay of the recalcitrant litter is 0 if $\mathrm{p}_{\mathrm{mRec}}=1$ and is unaffected if $\mathrm{p}_{\mathrm{mRec}}=0$. The reason for choosing a different equation than above is that constrain of labile litter decomposition by $\mathrm{C}: \mathrm{N}$ ratio should not completely stop decomposition but adjust the decomposition rate, while recalcitrant fraction of litter could remain almost constant for long periods. The following equations determine if the recalcitrant fraction of litter remains stable or if it is affected by decomposers partially or even totally.

$$
\begin{aligned}
& \text { fungi: } \mathrm{m}_{\mathrm{rec}_{\text {fung }}}=\min \left(1,1-\mathrm{p}_{\mathrm{mRec}} \operatorname{Rec}_{\text {fung }}\right) \\
& \text { bacteria: } \mathrm{m}_{\text {rec }}=\min \left(1,1-\mathrm{p}_{\mathrm{mRec}} \operatorname{Rec}_{\text {bact }} \operatorname{Rec}_{\text {lit }}\right)
\end{aligned}
$$

\section{Adding up all these modifying effects on $g_{\max }$}

We assume a complete additivity of the effects, so the different modifiers on $\mathrm{g}_{\max }$ are multiplied to get the overall effect, $m_{\text {tot }}$ in equation 25 . Another optional approach could be to use only the most limiting effect, setting $\mathrm{m}_{\text {tot }}$ equal to the lowest modifier and ignoring the rest.

$\mathrm{m}_{\mathrm{tot}}=\mathrm{m}_{\mathrm{T}} \mathrm{m}_{\mathrm{C}: \mathrm{N}} \mathrm{m}_{\mathrm{rec}} \mathrm{m}_{\mathrm{pH}} \mathrm{m}_{\mathrm{H} 2 \mathrm{O}}$

\section{$\underline{\text { Not assimilated C }}$}

The reduction in a substrate equals the growth of the consumer plus the $\mathrm{C}$ that goes to faeces (excrements) and to respiration. Fraction to excrement $\left(f_{\text {faec }}\right)$ is a parameter of the consumer and assumed constant. However, one consumes more and a larger fraction becomes faeces at a lower substrate quality, for the meso- and macro fauna, because microbes do not produce excrements; the sensitivity of $\mathrm{f}_{\text {faec }}$ to $\mathrm{C}: \mathrm{N}$ ratio is expressed by the modifier $\mathrm{m}_{\text {faec }}$. This is however only relevant for the detritivores and engineers (equation 26) that eat SOM and litter which can contain extremely variable amounts of nutrients; for the predators and herbivores we assume the variability is minimal. For the microbes, it was calculated as an effect on $g_{\max }$. 
$334 \mathrm{f}_{\text {faecEff }}=\mathrm{f}_{\text {faec }}+\mathrm{m}_{\text {faec }} \frac{\mathrm{C:N}_{\mathrm{SOM}}-\mathrm{C}: \mathrm{N}_{\text {eng }}}{\mathrm{C}: \mathrm{N}_{\mathrm{SOM}}} \mathrm{f}_{\text {faec }}$

335

336

337

338

339

340

341

342

343

344

345

346

347

348

349

350

351

352

353

354

355

356

357

358

359

360

361

362

363

364

365

366

367

368

369

370

371

$\underline{\text { Calculations regarding engineers }}$

Soil changes made by engineer species depend on their body width, but in the model this is simplified using initial parameters for engineers' effects that must be chosen based on an average width (see Table S2.5 in Supplemental File S2); the model then simulates their daily effects using their biomasses. Bioturbation is a function of engineer biomass $\left(\mathrm{B}_{\mathrm{eng}}, \mathrm{g} \mathrm{C} \mathrm{m}^{-3}\right)$, which calculates organic matter moving to deeper layers: litter moving $\left(\mathrm{g} \mathrm{C}_{\mathrm{lit}} \mathrm{g} \mathrm{C}_{\mathrm{eng}}{ }^{-1}\right.$ day $\left.^{-1}\right)$ from litter layer to end of burrow, and SOM moving by mixing of soil between layers $\left(\mathrm{g} \mathrm{C}_{\mathrm{SOM}} \mathrm{g} \mathrm{C}_{\mathrm{eng}^{-1} \mathrm{day}^{-}}\right.$ $\left.{ }^{1}\right)$. In this first version of the model, with only one soil layer, bioturbation works as a $\mathrm{C}$ output flow, but in future versions with more layers it could be upgraded to $\mathrm{C}$ flows between them.

Burrow volume $\left(\mathrm{PV}_{\mathrm{B}}, 1 \mathrm{~m}^{-3}\right)$ is a function of engineer biomass $\left(\mathrm{g} \mathrm{C}_{\mathrm{eng}} \mathrm{m}^{-3}\right)$ and the ratio of pore volume to engineer biomass $\left(\mathrm{VE}_{\text {ratio }}, 1 \mathrm{~g} \mathrm{C}_{\mathrm{eng}}{ }^{-1}\right)$ but towards a maximum $\left(\mathrm{PV}_{\mathrm{Bmax}}, 1 \mathrm{~m}^{-3}\right)$. On the other hand, burrow turnover $\left(\mathrm{tPV}_{\mathrm{B}}\right)$ happens at a constant rate, with average burrow lifespan of 10 years; porosity decreases and burrows become mesopores.

$P V_{B}=\max \left(\min \left(\mathrm{PV}_{\mathrm{Bmax}}, \mathrm{VE}_{\text {ratio }} \mathrm{B}_{\text {eng }}\right),\left(\mathrm{PV}_{\text {macro }}-\mathrm{PV}_{\text {textmacro }}\right)\left(1-\mathrm{tPV}_{\mathrm{B}}\right)\right)$

where $\mathrm{PV}_{\text {macro }}$ is the current pore volume of the macropores and $\mathrm{PV}_{\text {textmacro }}$ is the textural porosity of the macropores (see in next section). This could be improved in future versions including perturbations as the possible effect of heavy rain.

\section{$\underline{\text { Porosity calculations }}$}

The pore volume is distributed in five classes by pore size. Initial pore size distribution is given or measured as the total pore volume $\left(\mathrm{PV}, 1 \mathrm{~m}^{-3}\right)$ in each class. The link between aggregation and porosity is hard to quantify. Regelink et al. (2015a) showed for different soils that overall soil porosity is the sum of the textural porosity determined by the proportion of clay, sand and silt fractions and aggregation porosity. They conclude that micropores, which they define $<9 \mu \mathrm{m}$, are mainly situated within the aggregates, while mesopores are situated between dry-sieved aggregates. While Regelink et al. (2015a) have shown that total micro and mesoporosity $(<1000$ $\mu \mathrm{m})$ increases with total aggregate content, Grosbellet et al. (2011) have provided evidence that pores in the range $30-300 \mu \mathrm{m}$ decrease with aggregation. Despite of the generally lower ranges for mesopores $(9-1000 \mu \mathrm{m})$ described for soil physics (Lal and Shukla, 2004; Regelink et al., 2015a), here mesopores are assumed to be physically accessible to mesofauna body size (ca. 100 $-2000 \mu \mathrm{m}$ ), so we consider that mesopores ranging $30-1500 \mu \mathrm{m}$ are a reasonable compromise. Based on that, we decided to hypothesize that aggregation increases bacterial and micro- porosity while decreasing mesoporosity. However, we want to emphasize that further experimental studies are needed to establish robust relationships between aggregation and pore size distribution. 
372

373

374

375

376

377

378

379

380

381

382

383

384

385

386

387

388

389

390

391

392

393

394

395

396

397

398

399

400

401

402

403

404

405

406

407

Aggregates are not calculated as a pool, but the effect of aggregation is included in the calculation of porosity as described below. The following three porosities contribute to total porosity:

- Textural porosity $\left(\mathrm{PV}_{\text {text }}\right)$ : measured or calculated from \% clay and sand.

- Additional aggregation porosity $\left(\mathrm{PV}_{\mathrm{Ag}}\right)$ : all porosity in surplus of textural, can be estimated, for example from PTF (PedoTransfer Function) or calculated empirically from SOM and fungal biomass, i.e. mycorrhiza and other fungi, max $2 \%$ porosity extra (equation 29). Aggregation (Ag) is the fraction (0-1) of the SOM aggregated calculated as (based on the data from Malamoud et al., 2009):

$\operatorname{Ag}=\min \left(1, \frac{\mathrm{c}\left(\mathrm{B}_{\text {fung }}+\mathrm{B}_{\text {myc }}\right)}{\mathrm{B}_{\text {SOM }}}\right)$

with an empirical parameter $\mathrm{c}=10$. The aggregation porosity is then calculated as:

$\mathrm{PV}_{\mathrm{Ag}}=\mathrm{kAg} \mathrm{B}_{\mathrm{SOM}}$

with $\mathrm{k}=$ coefficient $\left(21 \mathrm{~g} \mathrm{C}^{-1} \mathrm{~m}^{-3}\right)$ based on empirical data (Regelink et al., 2015a; Regelink et al., 2015b).

- Bioporosity $\left(\mathrm{PV}_{\mathrm{B}}\right)$ : biopores created by engineers. Pore formation by engineers increases macroporosity, increasing soil layer density, but at the same time reduces mesoporosity as engineers push soil aside and produce casts that are denser than average soil. The relative importance of these two effects depends on the engineers' activity patterns, and is reflected by the parameter $f_{P V} \in(0,1)$, which gives the fraction of the change in biopore volume that increases macroporosity. Therefore, the counterpart of the biopore volume (1 - $\left.f_{P V}\right) P_{B}$ is 'compensated' by a decrease in mesoporosity.

Conceptually, the total soil porosity is then the sum of:

$\mathrm{PV}_{\text {tot }}=\mathrm{PV}_{\text {text }}+\mathrm{PV}_{\mathrm{Ag}}+\mathrm{f}_{\mathrm{PV}} \mathrm{PV}_{\mathrm{B}}$

In the model, pore volume is calculated for each pore size separately.

The volume of micropores $\left(\mathrm{PV}_{\text {micro }}\right)$ and bacterial pores $\left(\mathrm{PV}_{\text {bact }}\right)$ increases with increasing aggregation. Apart from creating additional porosity depending on the total amount of aggregated SOM (eq. 29), aggregation also increases the relative micro- and bacterial pore volume at the expense of (textural) mesoporosity $\left(\mathrm{PV}_{\text {meso }}\right)$, therefore not increasing total porosity. This effect is controlled by available pore space between mineral particles (i.e. textural mesoporosity) and we assume that half of this mesoporosity can be affected by aggregation. In both cases, we assume that the increase in porosity due to aggregation is divided equally among micropores and bacterial pores. The pore volume in different size classes is calculated as:

$\mathrm{PV}_{\text {macro }}=\mathrm{PV}_{\text {textmacro }}+\mathrm{PV}_{\mathrm{B}}$

$\mathrm{PV}_{\text {meso }}=\mathrm{PV}_{\text {textmeso }}-\left(1-\mathrm{f}_{\mathrm{PV}}\right) \mathrm{PV}_{\mathrm{B}}-\frac{\mathrm{Ag}}{2} \mathrm{PV}_{\text {textmeso }}$

$\mathrm{PV}_{\text {micro }}=\mathrm{PV}_{\text {textmicro }}+\mathrm{k}_{\frac{\mathrm{Ag}}{2}} \mathrm{~B}_{\mathrm{SOM}}+\frac{\mathrm{Ag}}{4} \mathrm{PV}_{\text {textmeso }}$

$\mathrm{PV}_{\text {bact }}=\mathrm{PV}_{\text {textbact }}+\mathrm{k} \frac{\mathrm{Ag}}{2} \mathrm{~B}_{\mathrm{SOM}}+\frac{\mathrm{Ag}}{4} \mathrm{PV}_{\text {textmeso }}$ 
408

409

410

411

412

413

414

415

416

417

418

419

420

421

422

423

424

425

426

427

428

429

430

431

432

433

434

435

436

437

438

439

440

441

442

443

444

Volume of inaccessible pores is assumed to be constant and equal to $\mathrm{PV}_{\text {textinac }}$.

These changes are calculated daily to give a dynamic feedback to the hydrology and to the distribution of each $\mathrm{C}$ source among pore classes, affecting its availability.

\section{Leaching}

Water leaving one soil layer $(\mathrm{n})$ is moved to the layer below $(\mathrm{n}+1)$. Dissolved organic and inorganic compounds are a complex matter to simulate since they are strongly dependent on the $\mathrm{pH}$ and the mother-material, i.e. clay and Ca rich or not. Nonetheless, in many systems simulating leaching of $\mathrm{N}$ and DOM is highly relevant. Unless better data are available, we suggest the following, semi-empirical method:

DOM can be simulated in relation to the $\mathrm{CO}_{2}$ released as total respiration $\left(\mathrm{R}_{\mathrm{tot}}, \mathrm{g} \mathrm{C} \mathrm{m}^{-3}\right.$ day $\left.^{-1}\right)$ based on the consideration that high 'activity' in the soil is related to high $\mathrm{R}_{\text {tot }}$. This is calculated as a fraction ( $\left.f_{D O M}\right)$ of $R_{\text {tot }}$ entering the DOM pool, similar to the concepts used in the LIDEL model, in addition to the directly exuded DOM $\left(\mathrm{C}_{\text {Exud }}, \mathrm{g} \mathrm{C} \mathrm{m}^{-3}\right.$ day $\left.^{-1}\right)$ which is an input (from data or a vegetation model). Assuming a short half-life of DOM and semi-empirically, because daily concentration is not 'equal' to daily production $\left(\mathrm{DOM}_{\mathrm{p}}, \mathrm{g} \mathrm{C} \mathrm{m}^{-3} \mathrm{day}^{-1}\right)$ but is linearly related to the daily production, we consider:

$\mathrm{DOM}_{\mathrm{p}}=\mathrm{C}_{\text {Exud }}+\mathrm{f}_{\text {DOM }} \mathrm{R}_{\text {tot }}$

DOM has a short half-life but the dissolution is even faster (hours). We assume the daily concentration is in equilibrium between dissolved and adsorbed ( $\left.\mathrm{DOM}_{\mathrm{ad}}\right)$ depending on adsorption coefficient $\mathrm{K}_{\mathrm{D}}$ of the soil $\left(\mathrm{m}^{3} \mathrm{~kg}^{-1}\right.$ soil). Similar to the modelling in Orchidee-SOM (Cammino-Serrano et al., 2018) we assume:

$\mathrm{DOM}_{\mathrm{ad}}=\mathrm{K}_{\mathrm{D}} \mathrm{DOM}$

with $\mathrm{K}_{\mathrm{D}}$ depending on the minerals and $\mathrm{pH}$. More clay (fClay fraction) means less mobile DOM, and lower $\mathrm{pH}$ is also a cause of less mobile DOM.

$\mathrm{K}_{\mathrm{D}}=\mathrm{a}_{\mathrm{KD}}-\mathrm{b}_{\mathrm{KD}} \mathrm{pH}+\mathrm{c}_{\mathrm{KD}}$ fClay

with values $0.001226,0.000212$ and 0.00374 respectively for $\mathrm{a}_{\mathrm{KD}}, \mathrm{b}_{\mathrm{KD}}$ and $\mathrm{c}_{\mathrm{KD}}$, from CamminoSerrano et al. (2018).

DOM leaching is calculated as the volume of water leaching to a lower layer multiplied with the concentration of dissolved DOM.

\section{Calculation order}

The sequence of function sets used by the model to calculate all carbon fluxes and ecosystem changes is as follows:

a) Calculate the pore size fractions in 5 classes and the associated pore surface areas

b) Calculate the water volume of the relevant pore size

c) Use the precipitation leaching to calculate DOM leaching 
d) Calculate for each biota group the accessibility of each of the pools it consumes

e) Calculate the $\mathrm{g}_{\max }$ depending on temperature, $\mathrm{H}_{2} \mathrm{O}, \mathrm{C}: \mathrm{N}, \mathrm{pH}$ and recalcitrance

f) Solve the 12 differential equations for increase/decrease of all $\mathrm{C}$ pools

g) Update all C pools

h) Calculate the new $\mathrm{C}: \mathrm{N}$ and recalcitrance of each pool

i) Calculate engineering effect

a. Update macropores

b. Update SOM from bioturbation

j) Calculate other changes in pore size distribution from weather or management

The KEYLINK core model consists of steps $d$ to $i$; steps a, b, c and $j$ are add-ons that could be replaced by other models (e.g. water flow model) coupled to KEYLINK. Steps a-c are used to calculate the distribution of porosity between the pore classes, the hydrology and daily soil water content (distributed among pore classes), and then step d calculates how that is affecting the availability of each $\mathrm{C}$ source to its consumers. That couples soil structure and hydrology with trophic interactions, allowing the resolution of differential equations for $\mathrm{C}$ fluxes.

Model coding and output

KEYLINK consists of a relatively limited, freely downloadable Python code (available at: https://github.com/Plant-Root-Soil-Interactions-Modelling/KEYLINK). Each of the modifiers on growth, i.e. temperature, $\mathrm{pH}, \mathrm{H}_{2} \mathrm{O}$, recalcitrance and $\mathrm{C}: \mathrm{N}$, as well as the primal shape of the growth equations can be adapted towards specific questions or ecosystems. The inputs in the current version are read from data-files but are easy to link to a mechanistic model. The output of the current version consists of all daily $\mathrm{C}$ pools as well as the main $\mathrm{C}$ fluxes. KEYLINK is also available as a stand-alone executable model, allowing it to be called from models in other languages. A single run of ten years could take less than one minute (depending on computing power). In this version, the average results over one hundred runs are calculated but also all daily outputs of each run are saved.

\section{Model parameterization}

The first version of KEYLINK model has been parameterized for a Scots pine forest stand situated in Brasschaat, in the Campine region in Belgium (51 ${ }^{\circ} 18^{\prime} \mathrm{N}$ and $4^{\circ} 31^{\prime} \mathrm{E}$ ) but without modelling the complete forest ecosystem (to simplify the interpretation of the results from KEYLINK). The goal of this parameterization was a model verification, not a model application for which a complete integration with an aboveground model or detailed above ground data would be necessary.

The soil of the Brasschaat forest is sandy but with high ground water table, so trees are generally not water-limited, but the topsoil is often dry. The soil is acidic $(\mathrm{pH} 3.5)$. The trees were planted around 1930 and formed a rather sparse vegetation in 1999, with leaf area index (LAI) ranging from 2.1 to 2.4 .

For this model run, we used the following input data from the stand (Table 1). In this case, we did not use measured or modelled growing trees but constant input of aboveground and 
486

487

488

489

490

491

492

493

494

495

496

497

498

499

500

501

502

503

504

505

506

507

508

509

510

511

512

513

514

515

516

517

518

519

520

521

\section{2}

523

524

525

526

belowground litter (measured value). The top $90 \mathrm{~cm}$ of soil from the Brasschaat forest was analyzed in 1999 by Janssens et al. Earthworm biomass, used in this case as an example of ecosystem engineers, is extremely low due to the low $\mathrm{pH}$, it was not measured since 1993 by Muys, but these data are used since there is no reason to expect there was a marked change.

Data availability on soil pools, biology and functioning is generally low, and it is currently not possible to find a dataset describing in detail, and with small error margins, the temporal evolution of all different soil biological compartments and SOM pools. Available data are often incomplete, or based on rough estimates, e.g. from semiquantitative DNA analysis for microbial abundance in soils. To deal with this issue, a quite pragmatic approach combining different estimates from different sources is appropriate for most datasets where the soil is not the key focus, but a means to improve the simulation of an ecosystem.

The daily loss of water by evapotranspiration was calculated using an equation for potential evapotranspiration based on Thornthwait (1948) in this study.

\section{Model calibration}

Once the model is parameterized for an ecosystem, the next step is to optimize that model, calibrating the fit of its simulations to the ecosystem data. The optimization included in the KEYLINK model follows a Bayesian procedure (Van Oijen, Rougier and Smith, 2005; Van Oijen, 2008).

A pragmatic assumption is that the starting values of the $\mathrm{C}$ pools (including the soil fauna initial biomasses) are at steady state for a given date (most often spring or summer, it would be unrealistic to keep the values constant through the year as they fluctuate with climate). The simplest calibration of any ecosystem can be done by assuming these 11 carbon pools (litter, SOM and the 9 functional groups in food web) need to be stable over the simulated years, e.g. for 9 years that gives us 99 data points by taking the same value for each $\mathrm{C}$ pool every year (Table 2). Initial litter, SOM and biomasses of bacteria, fungi and engineers were taken from the references cited in Table 1. For other $\mathrm{C}$ pools, data were estimated using measured data for previous $\mathrm{C}$ pools and similar proportions between $\mathrm{C}$ pools as in the Swedish pine forest in Persson et al. (1980); predator biomass was assumed to be the $20 \%$ of all biomass in their consumed $\mathrm{C}$ pools. Errors were assumed as a percentage of biomass, $10 \%$ for predators, $12.5 \%$ for litter and SOM, and $20 \%$ for the rest C pools.

It is common to apply a correction ("burn-in") deleting part of the posterior, e.g. the first half of the runs, to avoid the effect of the starting distribution (Gelman and Shirley, 2011). For this calibration, a sample of the last one hundred accepted parameter vectors was taken from the posterior distribution, and it was used for all further model runs, so every run was performed with 100 different parameter sets.

\section{$\underline{\text { Input parameters of species }}$}

The KEYLINK model framework is conceptualized as an adaptable framework. Each user needs to determine for their specific site and questions the main drivers and pools required. Depending on the dataset, it is in general better to use less pools and equations if sparse data are available. Moreover, KEYLINK is not a soil fauna model and was not designed to simulate specific soil

Peer) reviewing PDF | (2020:03:47320:2:0:NEW 17 Nov 2020) 
527 fauna species in detail. The soil fauna groups used consist of a wide range of species, for which 528 average data are used. For a description of the species categories, we refer to the review on the 529 KEYLINK concepts (Deckmyn et al., 2020).

530 Microbes and meso-macro fauna have a temperature curve using an optimum, minimum and 531 maximum temperature. Each soil biota group also has its own maximum growth rate, $\mathrm{C}: \mathrm{N}$ ratio, 532 respiration rate and size. Death rate (d) is the inverse of turnover, mostly given in days. In 533 Supplemental File $\mathbf{S 1}$ we briefly review main input parameters. We propose setting $\mathrm{K}_{\mathrm{s}}$, the 534 concentration of the food source at which growth rate is half the maximum, equal to the existing 535 concentrations for all meso- and macro fauna, so assuming growth could double at unlimited

536 food source. But for microbial biomass the difference between growth of bacteria on a petri-dish 537 unlimited in nutrients compared to field data of soil microbes clearly indicates that $\mathrm{g}_{\max }$ in the 538 soil is not comparable to laboratory data; if such data of $g_{\max }$ are used, the $\mathrm{K}_{\mathrm{s}}$ should be increased 539 considerably.

\section{Calibration for Brasschaat pine forest}

542 We show here the results from a calibration towards data measured and assumed, using proportions between fauna groups in Persson et al. (1980), in the Brasschaat Scots pine stand in Belgium. This forest stand is relatively well described in many publications concerning the trees and the total ecosystem fluxes, but less concerning the soil and very little was measured on soil fauna. Therefore, the partially assumed data refers to a hypothetical ecosystem that does not fully fit with reality in Brasschaat forest. We use this forest as an example of how the KEYLINK model can be used to improve our understanding of the system even when detailed soil faunal data are limited.

The parameters $g_{\max }, \mathrm{K}_{\mathrm{s}}$ and $\mathrm{r}$ are linked (increasing $\mathrm{g}_{\max }$ has a similar effect to decreasing $\mathrm{K}_{\mathrm{s}}$ or r). However, $g_{\max }$ or $r$ ranges can be found in literature relatively easily. Therefore, we use fixed values for $\mathrm{K}_{\mathrm{s}}$ (see Supplemental File $\mathbf{S 2}$ ) and parameterize $\mathrm{g}_{\max }$ within the known limits. In this way, the number of parameters to be calibrated is 9 , which is a reasonable number for most cases where limited data to calibrate towards are available. Of course, a user could decide to optimize more parameters if more data are available. A useful 'rule of the thumb' is limiting the number of parameters to the square root of the number of calibration data available (Jörgensen, 2009), which means we can get a reasonable result for nine parameters assuming 81 data points.

In our case, no measurements of growth rates were available and information in the literature was scant. Therefore, we deliberately defined wide ranges for the prior values of each parameter to cover all the possible values found in the literature (Chuine, 2000; Linkosalo, Lappalainen and Hari, 2008). For species for which no prior parameter information was available, we assumed parameter values equal to the mean value of the range. The initial uncertainty of each parameter is quantified in terms of a prior probability distribution with lower and upper bounds. Because of lack of detailed knowledge, we assumed the distribution as uniform and non-correlated.

565 The $g_{\max }$ values were optimized using the prior range for $g_{\max }$ (Table 3 ). The data used to 566 calibrate against were chosen to give a 'standard' procedure, so limited to biomass of the 567 different $C$ pools. Including all available data s.a. soil respiration, soil humidity could improve 568 the run for Brasschaat, but would not be a representative run for the model. Other parameter 
569 settings, e.g. sensitivity to $\mathrm{C}: \mathrm{N}$ and recalcitrance, were based on model runs of the Brasschaat 570 site by Deckmyn et al. (2011).

571 We ran the model for the time period 1999-2008, because this was the period in which the forest 572 was still clearly dominated by Scots pine; since then a transition to more deciduous trees has 573 been taking place. We calibrated towards stable $\mathrm{C}$ pools over the ten years for all $\mathrm{C}$ pools, with 574 an allowed error margin of $20 \%$ for all faunal pools, except $10 \%$ for predators, and $12.5 \%$ for 575 litter and SOM. Daily climate data (temperature and precipitation) were used. The full range of

576 input data can be found in Supplemental File S2, except climate data, which can be downloaded 577 with the model. Choosing to calibrate towards one or more pools can yield different results, and 578 it depends on the end-user's goal which calibration is preferred.

579

580

Model evaluation

581

Although coupling KEYLINK to real or simulated data of the aboveground ecosystem would yield more realistic results, in this exercise we used KEYLINK as a stand-alone model with quite constant input (e.g. litter, plant water uptake) to minimize the feedback effects and give a clear view on the model behaviour. This is a model evaluation, not a full model validation.

After calibration to the Brasschaat dataset, a set of scenarios was performed to evaluate the model: I. Basic results; II. Sensitivity to initial soil structure; III. Changing initial litter C:N ratio; IV. Changing initial litter recalcitrance; V. Changing soil pH; VI. Excluding predators.

Scenario I was done with the reference input parameters (Supplemental File S2), and used as a basal one to be compared with the other five alternative scenarios: scenario II with higher clay content in the soil (clay 15\%); scenario III with lower litter C: $\mathrm{N}$ ratio (40); scenario IV with lower litter recalcitrance (20\%); scenario $\mathrm{V}$ with higher $\mathrm{pH}(5.9)$; and scenario VI without predators by setting its initial biomass to $0\left(\mathrm{~B}_{\text {pred }}=0\right)$.

In each one of the five alternative scenarios, input parameters were the same than in the basal

594 scenario, except for the parameter changed to generate the new scenario (see Supplemental File S2). All the six scenarios were run 100 times using a sample of 100 parameter vectors from the posterior distribution of the calibration, consisting each run in a simulation of 10 years at a daily time-step (3653 days). Then, averages of biomasses were calculated for each $\mathrm{C}$ pool among the 100 simulations of 10 years, for each scenario, comparing the effects of disturbances on average values.

600

601

\section{Results}

602

\section{$\underline{\text { Calibration }}$}

603

The model was run ca. 100000 times with different parameter settings sampled from the prior parameter distribution. A sample of the posterior distribution was taken with the last 100 accepted parameter vectors for $g_{\max }$ (Table 4).

606 The optimization showed the link between the different groups of soil biota, e.g. a high $g_{\max }$ for 607 bacteria was coupled to a high $g_{\max }$ for bacterivores. The alternative five scenarios compared to 
608 the basal one can show very different results concerning specific C pools (Table 5). Running the 609 model 100 times using the sample of the $g_{\max }$ values resulted in predictions with a quite wide 610 range (Table 6).

611 Basic results

612 Mycorrhiza, herbivores and detritivores are relatively uncoupled, though influenced by 613 predators, and follow the yearly climate curves. The bacterial and fungal biomasses are very 614 strongly linked. The high $\mathrm{g}_{\max }$ of bacteria allows steep peaks, which are generally followed by 615 peaks in bacterivore biomass. As we used constant litter input into the soil and used a calculated 616 constant fraction of potential evapotranspiration as water uptake from the soil, it cannot be 617 expected that these results follow the normal annual trends in fluctuations of those fluxes. This 618 can, at least partially, explain the relatively low bacterial biomass found in our results, since the 619 bacteria would profit most from a rapidly changing environment, but under some unrealistic 620 simulated conditions fungi could be displacing bacteria by competitive exclusion. For more 621 realistic simulations the model can be coupled with other models that give that information as 622 outputs, or with measured datasets.

623 All C pools tend to reach some stability after the first years, suggesting the model is well624 balanced; however, stability values seem to be more sensitive to changes in $\mathrm{g}_{\max }$ parameters for 625 some pools (e.g. SOM). The set-up of the model, where we only calibrate the faunal $\mathrm{g}_{\max }$, does 626 not allow calibration towards different ratio of litter and SOM decay. This depends on the uncalibrated parameter fragmentation, the sensitivity to recalcitrance, but also the temperature used for the litter and SOM. Here we used the same temperature, while in reality it would be expected that there would be certain differences in mean temperatures or their variability at different depths.

There was a high variability within the 100 simulations of each scenario, e.g. basal scenario (Fig. 3), calling into question the reliability of predictions. We suggest here some theoretical predictions based on this example, but it is clear that for a realistic application it will be necessary to improve the calibration, by using more detailed data or by linking the model to a vegetation model. This highlights the relevance of developing databases including enough details for the key parameters of the different parts of the soil system (i.e. soil structure, hydrology, food webs).

An overview of all $\mathrm{C}$ pools under the different simulation scenarios (Fig. 4) shows how changing one input parameter at a time influences the results. It must be taken into account that KEYLINK was run as a stand-alone model, which can explain why some of the resulting outputs seem not very realistic; linking it to a model or more detailed data of the aboveground ecosystem would greatly influence the results, but would not allow clear interpretation of the model functioning due to feedbacks. Since our goal here was to introduce the belowground model itself rather than a realistic application to a particular case, we chose to avoid those feedbacks with other parts of the ecosystem that are required for more realistic simulations. To further elucidate these effects and to show some of the potential outputs the model can give, we show a few of the most interesting fluxes (Table 7).

648 The simulated scenarios showed that increasing clay content (i.e. changing initial soil structure) 649 resulted in an increase in water content (Fig. 5) and a decrease in litter and SOM decay while 650 fungal/bacterial ratio decreased. In fact, this scenario caused the largest change in soil water 
651 content, showing the sensitivity of the system to initial soil structure and its crucial role for soil 652 hydrology. On the other hand, lowering litter recalcitrance or C:N ratio resulted in an increase in 653 microbial biomass, mainly fungi, which caused an increase in litter decay, while SOM decay did 654 not show a clear change. The scenario with higher $\mathrm{pH}$ allowed engineer species (and predators 655 with them) to increase in biomass, altering the soil structure with an increase in macroporosity, 656 which caused a clear decrease in SOM stabilization. Finally, the exclusion of predators totally 657 changed the soil porosity and the trophic interactions along the food web, causing the largest 658 increase in the decay of SOM and litter, which highlights the crucial role of predators in the 659 regulation of the soil $\mathrm{C}$ cycle.

660

661

662

\section{Discussion}

\section{3}

The Brasschaat forest is sandy, with low $\mathrm{pH}$ and recalcitrant litter; as expected, this is an environment not suited to earthworms. The model correctly simulated extremely low values of engineer biomass. Increasing the $\mathrm{pH}$ increased the engineers pool, e.g. earthworms population, but this remained too low to have a significant impact on the system. This is quite realistic as neither litter quality nor soil quality are ideal for earthworms. Obviously, to calibrate the specific parameters concerning earthworms the Brasschaat forest is not an ideal site.

The high variability observed in some populations could make them appear more unstable than what can be expected in reality, and it is indeed expectable that a more realistic application of the model will yield different results. However, there are also empirical evidences that some populations, e.g. microbial biomasses, can be very unstable depending on hydrology (Blackwell et al., 2010; Zhao et al., 2010), showing short-term spikes in biomass as those observed in the presented simulations, in response to predicted changes in water availability.

Changes in litter quality (i.e. in $\mathrm{C}: \mathrm{N}$ ratio and recalcitrance) caused small differences between scenarios, being the simulations from those two alternative scenarios quite similar to the basal scenario. Despite the apparent increase in litter decay for lower litter recalcitrance and for lower $\mathrm{C}: \mathrm{N}$ ratio, as mentioned before, the high variability among simulations (Fig. 3) suggests that differences between scenarios caused by changes in litter quality are negligible. It is well known that litter quality is one of the main factors controlling litter decomposition rates (Zhang et al., 2008; García-Palacios et al., 2013), and the observed trend fits with experimental evidence, but clearer effects of changes in litter quality are expected. Therefore, these simulations should be tested again, particularly with the model linked to a vegetation model, and, if necessary, 684 improvements should be added.

Changes in textural porosity, on the other hand, showed clearer effects on soil processes. The scenario changing clay content to increase textural porosity caused the highest impact on hydrology, increasing soil water content (E in Figure 5), which led to a decrease in SOM availability, decreasing microbial community biomasses and, therefore, decreasing the decomposition of SOM and litter. However, changes in $\mathrm{C}$ pools were not as clear as in hydrology, mainly due to the high uncertainty in calibration results.

691 The scenario without predators showed the most interesting results because the interactions 692 between the different food web parts are apparent, and it showed a high contrast with the basal 
693

694

695

696

697

698

699

700

701

702

703

704

705

706

707

708

709

710

711

712

713

714

715

716

717

718

719

720

721

722

723

724

725

726

727

728

729

730

731

732

733

734

735

736

737 scenario. Exclusion of predators, setting the starting biomass of that pool at 0 , showed how the model tracks its crucial role in the ecosystem (Fig. 4). Predators produce a top-down trophic cascade on the food web, e.g. on herbivores and roots. Microbial decay is reduced as fungi and bacteria are consumed by the increased populations of bacterivores and fungivores. Despite of the decrease in bacteria and fungi, SOM and litter were also lower without predators. This could be explained by an increase in engineer populations with implications also on the soil matrix. Overall the model successfully tracked soil food web dynamics and also their interactions with soil porosity. The effect of larger soil predators (e.g. Araneae, Carabidae, Formicidae) slowing down SOM decomposition and enhancing its stabilization has been previously found in experiments (Kajak, 1995), as well as mycorrhiza effect on porosity by making aggregates (Siddiky et al., 2012). Those trophic cascade effects over SOM stabilization depends on environmental conditions such as rainfall, with predation on microbivores reducing litter decomposition rates in more humid sites, while reductions in rainfall could lead to a shift in that trend with predation on microbivores indirectly increasing litter decomposition rates (Lensing and Wise, 2006). The predicted effects of predator exclusion increasing SOM and litter decay have been found in different ecosystems, e.g. grasslands (Kajak, 1997) and forests (Lawrence and Wise, 2000), but contrasting results (e.g. Kajak, 1995; Lawrence and Wise, 2004) suggest that it is not a general pattern. Considering the high rainfall conditions at the modelled Belgian forest, and according to the suggested trends based on experimental research, soil predators feeding on microbivores at Brasschaat forest could promote SOM stabilization, which would fit with the simulated scenarios. Therefore, KEYLINK model seems to fit with the expected food web and $\mathrm{C}$ dynamics, and could serve to improve the biogeochemical cycles modelling, as is needed for larger scale predictions (Grandy et al., 2016), by coupling it with other ecosystem models.

Hydrology is influenced by aggregation and by macropore formation by ecosystem engineers. The increased macroporosity increases infiltration rate with reduced water-logging and runoff. Predators have a clear indirect effect on soil porosity by consuming engineer species, and also microbivore species, which leads to changes in soil hydrology (Fig. 5). Variations in bacterial pore and micropore volume are positively correlated, while mesopore variations are negatively correlated with both; the higher volume in mesopores, the lower in the two other classes, and the faster the water drains from the soil layer. That is what we can expect to happen in real soils, so the model seems to simulate appropriately those dynamics. The increase in macro and mesoporosity volumes without predators, so with higher engineers, resulted in a decrease of soil water content of $9.26 \%$ (increasing the pore aeration), and under those conditions the availability of SOM and litter for bacteria and fungi could be increased, explaining why SOM and litter are lower even with lower bacteria and fungi. This highlights the role of hydrology on trophic cascade processes, which can be enhanced or reduced by water distribution through the soil matrix (Erktan, Or and Scheu, 2020), and also the relevance of considering how climate change effects on soil structure, hydrology and food web interactions (particularly trophic cascades) can affect microbial communities (Thakur and Geisen, 2019) and, therefore, litter and SOM decomposition.

The aim of this study was to present a first version of a new concept model that hopefully will serve to challenge current state-of-the-art soil modelling. But we are aware that to do that we will need to improve the calibration of the model in the future, using more complete databases that take into account all the elements needed to calibrate KEYLINK, which, on the other hand, are 
738

739

740

741

742

743

744

745

746

747

748

749

750

751

752

753

754

755

756

757

758

759

760

761

762

763

764

765

766

767

768

769

770

771

772

773

774

775

776

currently extremely scarce. By presenting this concept model that challenges the current way of simulating soil biochemical cycling, we hope to stimulate that future studies will also be designed to take into account the pools and functional groups needed to calibrate KEYLINK.

\section{Conclusions}

KEYLINK is a relatively simple, fast and easy to modify soil model that can be used as a standalone model to understand soil systems, or linked to detailed aboveground data/models to predict SOM turnover. Model evaluation showed that KEYLINK is capable of simulating properly not only the soil food web and $\mathrm{C}$ pools dynamics, but also how they interact with soil porosity and hydrology, which is one of the main goals of this new model. The results from the evaluation scenarios showed that SOM turnover is driven not only by microbial biomass, but also by soil structure and hydrology. Moreover, microbial biomass is strongly regulated by the presence/absence of the other soil fauna. Especially the effects of the predators and the ecosystem engineers are extremely significant for our understanding of soil functioning. Furthermore, since management can differentially affect the larger soil fauna, KEYLINK can be of great use to investigate potential effects of management changes on soil SOM, nutrient turnover and hydrology.

This model shows degradability of SOM can be adequately simulated from accessibility in relation to pore space instead of the existing concepts of slow and fast pools. This allows a closer link to the soil structure and soil fauna which we consider closer to the actual, and follows the concepts as first described by Kuka, Franko and Rühlmann (2007), but applied here in a wider framework and including the hydrology.

For a full validation or better calibration of the model, datasets are required including basic data on the aboveground, e.g. litter input, water uptake, root growth and turnover, in combination with relatively detailed data on soil structure, i.e. pore size distribution, and hydrology and soil biota, e.g. biomass of bacteria, fungi, mycorrhizal fungi and main meso-and macrofauna. All these data are available, but very seldom at one site as most studies are focused on one or other aspect of soil science.

In conclusion, KEYLINK is a step towards a new generation of ecosystems models that include functional diversity, trophic structures and ecological processes as important factors shaping soil/ecosystem carbon and water cycling. Future versions, fed by more detailed data, will need to be developed in order to improve our current predictive capacity.

\section{Acknowledgements}

The authors express their gratitude to all the people who have contributed to the BioLink and KEYSOM COST Actions, whose work contributed also to the development of the KEYLINK model.

\section{References}


777

778

779

780

781

782

783

784

785

786

787

788

789

790

791

792

793

794

795

796

797

798

799

800

801

802

803

804

805

806

807

808

809

810

811

812

813

814

Birch, L. (1948). The intrinsic rate of natural increase of an insect population. The Journal of Animal Ecology, 17(1), 15-26.

Blackwell, M. S. A., Brookes, P. C., de La Fuente-Martinez, N., Gordon, H., Murray, P. J., Snars, K. E., Williams, J. K., Bol, R., and Haygarth, P. M. (2010). Phosphorus solubilization and potential transfer to surface waters from the soil microbial biomass following drying-rewetting and freezing-thawing. In Advances in agronomy (Vol. 106, pp. 1-35). Academic Press.

Camino-Serrano, M., Guenet, B., Luyssaert, S., Ciais, P., Bastrikov, B., De Vos, B., Gielen, B., Gleixner, G., Jornet-Puig, A., Kaiser, K., Kothawala, D., Lauerwald, R., Peñuelas, J., Schrumpf, M., Vicca, S., Vuichard, N., Walmsley, D., and Janssens, I. A. (2018). ORCHIDEE-SOM: modeling soil organic carbon (SOC) and dissolved organic carbon (DOC) dynamics along vertical soil profiles in Europe. Geoscientific Model Development, 11(3), 937-957.

Campbell. E. E., Parton, W. J., Soong, J. L., Paustian, K., Hobb, N. T., and Cotrufo, M. F. (2016). Using litter chemistry controls on microbial processes to partition litter carbon fluxes with the Litter Decomposition and Leaching (LIDEL) model. Soil Biology and Biochemistry, 100, 160-174.

Campbell, E. E., and Paustian, K. (2015). Current developments in soil organic matter modeling and the expansion of model applications: a review. Environmental Research Letters, 10(12), 123004.

Chertov, O., Komarov, A., Shaw, C., Bykhovets, S., Frolov, P., Shanin, V., Grabarnik, P., Priputina, I., Zubkova, E., and Shashkov, M. (2017a). Romul_Hum - A model of soil organic matter formation coupling with soil biota activity. II. Parameterisation of the soil food web biota activity. Ecological Modelling, 345, 140-149.

Chertov, O., Shaw, C., Shashkov, M., Komarov, A., Bykhovets, S., Shanin, V., Grabarnik, P., Frolov, P., Kalinina, O., Priputina, I., and Zubkova, E. (2017b). Romul_Hum model of soil organic matter formation coupled with soil biota activity. III. Parameterisation of earthworm activity. Ecological Modelling, 345, 140-149.

Christian, P. R., and Casella, G. (1999). Monte Carlo statistical methods. Springer. New York.

Chuine, I. (2000). A unified model for budburst of trees. Journal of Theoretical Biology, 207(3), 337-347.

Cotrufo, M. F., Wallenstein, M. D., Boot, C. M., Denef, K., and Paul, E. (2013). The Microbial Efficiency-Matrix Stabilization (MEMS) framework integrates plant litter decomposition with soil organic matter stabilization: do labile plant inputs form stable soil organic matter? Global Change Biology, 19, 988-995.

Deckmyn, G., Campioli, M., Muys, B., and Kraigher, H. (2011). Simulating C cycles in forest soils: Including the active role of micro-organisms in the ANAFORE forest model. Ecological Modelling, 222, 1972-1985. 
815

816

817

818

819

820

821

822

823

824

825

826

827

828

829

830

831

832

833

834

835

836

837

838

839

840

841

842

843

844

845

846

847

848

849

850

851

852
Deckmyn, G., Meyer, A., Smits, M. M., Ekblad, A., Grebenc, T., Komarov, A., and Kraigher, H., (2014). Simulating ectomycorrhizal fungi and their role in carbon and nitrogen cycling in forest ecosystems. Canadian Journal of Forest Research, 44(6), 535-553.

Erktan, A., Or, D., and Scheu, S. (2020). The physical structure of soil: Determinant and consequence of trophic interactions. Soil Biology and Biochemistry, 107876.

Filser, J., Faber, J. H., Tiunov, A. V., Brussaard, L., Frouz, J., De Deyn, G., Uvarov, A. V., Berg, M. P., Lavelle, P., Loreau, M., Wall, D. H., Querner, P., Eijsackers, H., and Jiménez, J. J. (2016). Soil fauna: key to new carbon models. Communications in Soil Science and Plant Analysis, 2, 565-582.

Franko, U. (1989). C-und N-Dynamik beim Umsatz organischer Substanzen im Boaen. Diss., Berlin, Akad. Landwirtsch.

Freytag, H. E., and Luttich, M. (1985). Zum Einfluß der Bodenfeuchte auf die Bodenatmung unter Einbeziehung der Trockenraumdichte. Archiv für Acker-und Pflanzenbau und Bodenkunde, 29(8), 485-492.

García-Palacios, P., Maestre, F. T., Kattge, J., and Wall, D. H. (2013). Climate and litter quality differently modulate the effects of soil fauna on litter decomposition across biomes. Ecology letters, 16(8), 1045-1053.

Gaublomme, E., De Vos, B., and Cools, N. (2006). An indicator for microbial biodiversity in forest soils. Brussels (BE): Instituut voor Natuur-en Bosonderzoek (INBO). R.

Geisen, S., Briones, M. J., Gan, H., Behan-Pelletier, V. M., Friman, V.P., de Groot, G. A., Hannula, S. E., Lindo, Z., Philippot, L., Tiunov, A. V., and Wall, D. H. (2019). A methodological framework to embrace soil biodiversity. Soil Biology and Biochemistry, $136,107536$.

Gelman, A., and Shirley, K. (2011). Inference from simulations and monitoring convergence. In: Brooks, S., Gelman, A., Jones, G., and Meng, X. L. (eds.), Handbook of Markov Chain Monte Carlo, 6, 163-174. CRC press, USA.

Georgiou, K., Abramoff, R. Z., Harte, J., Riley, W. J., and Torn, M. S. (2017). Microbial community-level regulation explains soil carbon responses to long-term litter manipulations. Nature Communications, 8(1), 1-10.

Grandy, A. S., Wieder, W. R., Wickings, K., and Kyker-Snowman, E. (2016). Beyond microbes: Are fauna the next frontier in soil biogeochemical models? Soil Biology and Biochemistry, 102, 40-44.

Grosbellet, C., Vidal-Beaudet, L., Caubel, V., and Charpentier, S. (2011). Improvement of soil structure formation by degradation of coarse organic matter. Geoderma, 162(1-2), 27-38.

Horemans, J., Roland, M., Janssens, I., and Ceulemans, R. (2017). Explaining the inter-annual variability in the ecosystem fluxes of the Brasschaat Scots pine forest: 20 years of eddy flux and pollution monitoring. In: EGU General Assembly Conference Abstracts, 19, 10402. 
853

854

855

856

857

858

859

860

861

862

863

864

865

866

867

868

869

870

871

872

873

874

875

876

877

878

879

880

881

882

883

884

885

886

887

888

889

890

Janssens, I. A., Sampson, D. A., Cermak, J., Meiresonne, L., Riguzzi, F., Overloop, S., and Ceulemans, R. (1999). Above- and belowground phytomass and carbon storage in a Belgian Scots pine stand. Annals of Forest Science 56, 81-90.

Janssens, I. A., Sampson, D. A., Curiel Yuste, J., Carrara, A., and Ceulemans, R. (2002). The carbon cost of fine root turnover in a Scots pine forest. Forest Ecology and Management, 168(1-3), 231-240.

Jones, C. G., Lawton, J. H., and Shachack, M. (1994). Organisms as ecosystem engineers. Oikos 69, 373-386.

Jörgensen, S. E. (2009). Ecological modelling: an introduction. WIT press. ISBN 978-1-84564408-6

Kajak, A. (1995). The role of soil predators in decomposition processes. European Journal of Entomology, 92(3), 573-580.

Kajak, A. (1997). Effects of epigeic macroarthropods on grass litter decomposition in mown meadow. Agriculture, ecosystems \& environment, 64(1), 53-63.

Kuka, K., Franko, U., and Rühlmann, J. (2007). Modelling the impact of pore space distribution on carbon turnover. Ecological Modelling, 208(2-4), 205-306.

Lal, R., and Shukla, M. K. (2004). Principles of soil physics. CRC Press.

Lavelle, P., Chauvel, A., and Fragoso, C. (1995). Faunal activity in acid soils. In Plant-Soil Interactions at Low pH: Principles and Management (pp. 201-211). Springer, Dordrecht.

Lavelle, P., Spain, A., Blouin, M., Brown, G., Decaëns, T., Grimaldi, M., Jiménez, J. J., McKey, D., Mathieu, J., Velasquez, E., and Zangerlé, A. (2016). Ecosystem engineers in a selforganized soil: a review of concepts and future research questions. Soil Science, 181(3/4), 91-109.

Lawrence, K. L., and Wise, D. H. (2000). Spider predation on forest-floor Collembola and evidence for indirect effects on decomposition. Pedobiologia, 44(1), 33-39.

Lawrence, K. L., and Wise, D. H. (2004). Unexpected indirect effect of spiders on the rate of litter disappearance in a deciduous forest. Pedobiologia, 48(2), 149-157.

Lensing, J. R., and Wise, D. H. (2006). Predicted climate change alters the indirect effect of predators on an ecosystem process. Proceedings of the National Academy of Sciences, 103(42), 15502-15505.

Linkosalo, T., Lappalainen, H., and Hari, P. (2008). A comparison of phenological models of leaf bud burst and flowering of boreal trees using independent observations. Tree Physiology, 28(12), 1873-1882.

Malamoud, K., McBratney, A. B., Minasny, B., and Field, D. J. (2009). Modelling how carbon affects soil structure. Geoderma, 149, 19-26.

Mambelli, S., Bird, J. A., Gleixner, G., Dawson, T. E., and Torn, M. S. (2011). Relative contribution of foliar and fine root pine litter to the molecular composition of soil organic matter after in situ degradation. Organic Geochemistry, 42, 1099-1108.

Peer) reviewing PDF | (2020:03:47320:2:0:NEW 17 Nov 2020) 
891

892

893

894

895

896

897

898

899

900

901

902

903

904

905

906

907

908

909

910

911

912

913

914

915

916

917

918

919

920

921

922

923

924

925

926

927

928

929

Muys, B. (1993). A synecological evaluation of the earthworm activity and litter decomposition in Flemish forests in the context of sustainable forest management. D. Phil. Thesis, University of Ghent.

Osler, G. H., and Sommerkorn, M. (2007). Toward a complete soil C and N cycle: incorporating the soil fauna. Ecology, 88(7), 1611-1621.

Persson, T., Bååth, E., Clarholm, M., Lundkvist, H., Soderstroem, B. E., and Sohlenius, B. (1980). Trophic structure, biomass dynamics and carbon metabolism of soil organisms in a Scots pine forest. Ecological Bulletins, 32, 419-459.

Regelink, I. C., Stoof, C. R., Rousseva, S., Weng, L., Lair, G. J., Kram, P., Nikolaidis, N. P., Kercheva, M., Banwart, S., and Comans, R. N. J. (2015a). Linkages between aggregate formation, porosity and soil chemical properties. Geoderma 247, 24-37.

Regelink, I. C., Weng, L., Lair, G. J., and Comans, R. N. J. (2015b). Adsorption of phosphate and organic matter on metal (hydr)oxides in arable and forest soil: a mechanistic modelling study. European Journal of Soil Science, 66(5), 867-875.

Rousk, J., Bååth, E., Brookes, P. C., Lauber, C. L., Lozupone, C., Caporaso, J. G., Knight, R., and Fierer, N. (2010). Soil bacterial and fungal communities across a $\mathrm{pH}$ gradient in an arable soil. The ISME journal, 4(10), 1340-1351.

Rousk, J., Brookes, P. C., and Bååth, E. (2009). Contrasting soil pH effects on fungal and bacterial growth suggest functional redundancy in carbon mineralization. Applied and Environmental Microbiology, 75(6), 1589-1596.

Rousk, J., Brookes, P. C., and Bååth, E. (2010). Investigating the mechanisms for the opposing $\mathrm{pH}$ relationships of fungal and bacterial growth in soil. Soil Biology and Biochemistry, 42(6), 926-934.

Saxton, K. E., Rawls, W., Romberger, J. S., and Papendick, R. I. (1986). Estimating generalized soil-water characteristics from texture 1. Soil Science Society of America Journal, 50(4), 1031-1036.

Schmidt, M. W. I., Torn, M. S., Abiven, S., Dittmar, T., Guggenberger, G., Janssens, I. A., Kleber, M., Kögel-Knabner, I., Lehmann, J., Manning, D. A. C., Nannipieri, P., Rasse, D. P., Weiner, S., and Trumbore, S. E. (2011). Persistence of soil organic matter as an ecosystem property. Nature, 478, 49-56.

Siddiky, R. K., Kohler, J., Cosme, M., and Rillig, M. C. (2012). Soil biota effects on soil structure: interactions between arbuscular mycorrhizal fungal mycelium and collembola. Soil Biology and Biochemistry, 50, 33-39.

Thakur, M. P., and Geisen, S. (2019). Trophic regulations of the soil microbiome. Trends in microbiology, 27(9), 771-780.

Thornthwait, C. W. (1948). An approach toward a rational classification of climate. Geographical Review, 38(1), 55-94.

Van Oijen, M. (2008). Bayesian Calibration (BC) and Bayesian Model Comparison (BMC) of process-based models: Theory, implementation and guidelines. 
930

931

932

933

934

935

936

937

938

939

940

941

942

943

944

945

946

947

948

949

950

951

952

953

954

955

956
Van Oijen, M., Rougier, J., and Smith, R. (2005). Bayesian calibration of process-based forest models: bridging the gap between models and data. Tree Physiology, 25(7), 915-927.

Vereecken, H., Schnepf, A., Hopmans, J. W., Javaux, M., Or, D., Roose, T., Vanderborght, J., Young, M. H., Amelung, W., Aitkenhead, M., Allison, S. D., Assouline, S., Baveye, P., Berli, M., Brüggemann, N., Finke, P., Flury, M., Gaiser, T., Govers, G., Ghezzehei, T., Hallett, P., Hendricks Franssen, H. J., Heppell, J., Horn, R., Huisman, J. A., Jacques, D., Jonard, F., Kollet, S., Lafolie, F., Lamorski, K., Leitner, D., McBratney, A., Minasny, B., Montzka, C., Nowak, W., Pachepsky, Y., Padarian, J., Romano, N., Roth, K., Rothfuss, Y., Rowe, E. C., Schwen, A., Šimůnek, J., Tiktak, A., Van Dam, J., van der Zee, S. E. A. T. M., Vogel, H. J., Vrugt, J. A., Wöhling, T., and Young, I. M. (2016). Modeling soil processes: Review, key challenges, and new perspectives. Vadose Zone Journal, 15(5).

von Lützow, M., Kögel-Knabner, I., Ludwig, B., Matzner, E., Flessa, H., Ekschmitt, K., Guggenberger, G., Marschner, B., and Kalbitz, K. (2008). Review Article Stabilization mechanisms of organic matter in four temperate soils: Development and application of a conceptual model. Journal of Plant Nutrition and Soil Science, 171(1), 111-124.

Wieder, W. R., Grandy, A. S., Kallenbach, C. M., and Bonan, G. B. (2014). Integrating microbial physiology and physio-chemical principles in soils with the MIcrobial-MIneral Carbon Stabilization (MIMICS) model. Biogeosciences, 11, 3899-3917.

Wieder, W. R., Grandy, A. S., Kallenbach, C. M., Taylor, P. G., and Bonan, G. B. (2015). Representing life in the Earth system with soil microbial functional traits in the MIMICS model. Geoscientific Model Development Discussions, 8(2), 1789-1808.

Zhang, D., Hui, D., Luo, Y., and Zhou, G. (2008). Rates of litter decomposition in terrestrial ecosystems: global patterns and controlling factors. Journal of Plant Ecology, 1(2), 8593.

Zhao, B., Chen, J., Zhang, J., and Qin, S. (2010). Soil microbial biomass and activity response to repeated drying-rewetting cycles along a soil fertility gradient modified by long-term fertilization management practices. Geoderma, 160(2), 218-224. 


\section{Table $\mathbf{1}$ (on next page)}

Initial input data.

Data from Brasschaat Scots pine forest (Belgium). Microbial C pool was estimated as hot water extractable C (HWC). 


\begin{tabular}{|c|c|c|c|}
\hline Variable & Unit & Value & Reference \\
\hline Earthworm biomass & $\mathrm{g} \mathrm{C} \mathrm{m}^{-3}$ & 200 & Muys (1993) \\
\hline $\mathrm{pH}$ & & 3.5 & Janssens et al. (1999) \\
\hline Sand & $\%$ & 93 & Janssens et al. (1999) \\
\hline Initial SOM & $\mathrm{g} \mathrm{C} \mathrm{m}^{-3}$ & 11470 & Janssens et al. (1999) \\
\hline Initial litter & $\mathrm{g} \mathrm{C} \mathrm{m}^{-3}$ & 2680 & Janssens et al. (1999) \\
\hline Fine root biomass & $\mathrm{g} \mathrm{C} \mathrm{m}^{-3}$ & 400 & Janssens et al. (2002) \\
\hline Fine root litter & $\mathrm{g} \mathrm{C} \mathrm{m}^{-3}$ & 300 & Janssens et al. (1999) \\
\hline Fine root growth rate & $\mathrm{g} \mathrm{C} \mathrm{m}^{-3}$ year $^{-1}$ & 210 & Janssens et al. (2002) \\
\hline Annual litter fall & $\mathrm{g} \mathrm{C} \mathrm{m}^{-3}$ year $^{-1}$ & 400 & Horemans et al. (2017) \\
\hline Fine root turnover & $\mathrm{g} \mathrm{C} \mathrm{m}^{-3}$ year $^{-1}$ & 740 & Based on Janssens et al. (2002) \\
\hline C input to mycorrhiza & $\mathrm{g} \mathrm{C} \mathrm{m}^{-3}$ year $^{-1}$ & 197 & Assumed based on Deckmyn et al. (2014) \\
\hline Microbial $\mathrm{C}$ as $\mathrm{HWC}$ & $\mathrm{g} \mathrm{m}^{-3}$ & 1338.21 & Gaublomme et al. (2006) \\
\hline
\end{tabular}

1 


\section{Table 2 (on next page)}

Calibration data.

Data of $C$ pools used for the model calibration. Biomasses of the nine food web functional groups: bacteria $\left(B_{b}\right)$, fungi $\left(B_{f}\right)$, mycorrhiza $\left(B_{\text {myc }}\right)$, bacterivores $\left(B_{\text {bvores }}\right)$, fungivores $\left(B_{\text {fvores }}\right)$, detritivores $\left(B_{\text {det }}\right)$, engineers $\left(B_{\text {eng }}\right)$, herbivores $\left(B_{\text {hvores }}\right)$ and predators $\left(B_{\text {pred }}\right)$; and the other two C pools: litter and soil organic matter (SOM). Values were used once per year during calibration at days 180, 545, 910, 1275, 1640, 2005, 2370, 2735 and 3100. 


\begin{tabular}{|c|c|c|}
\hline C pool & Value $\left(\mathrm{g} \mathrm{C} \mathrm{m}^{-3}\right)$ & Error $\left(\mathrm{g} \mathrm{C} \mathrm{m}^{-3}\right)$ \\
\hline $\mathbf{B}_{\mathrm{b}}$ & 15.1 & 3.02 \\
\hline $\mathbf{B}_{\mathbf{f}}$ & 15.1 & 3.02 \\
\hline$B_{\text {myc }}$ & 160 & 32 \\
\hline $\mathbf{B}_{\text {bvores }}$ & 0.1 & 0.02 \\
\hline $\mathbf{B}_{\text {fvores }}$ & 0.8 & 0.16 \\
\hline $\mathbf{B}_{\text {det }}$ & 0.6 & 0.12 \\
\hline $\mathbf{B}_{\text {eng }}$ & 0.2 & 0.04 \\
\hline B $_{\text {hvores }}$ & 0.2 & 0.04 \\
\hline $\mathbf{B}_{\text {pred }}$ & 0.4 & 0.04 \\
\hline Litter & 2680 & 335 \\
\hline SOM & 11470 & 1433.75 \\
\hline
\end{tabular}

1 


\section{Table 3 (on next page)}

Lower and upper bounds for the $g_{\max }$ prior probability distribution, for each one of the nine functional groups in the food web. 


\begin{tabular}{|c|c|c|}
\hline gmax & Lower bounds & Upper bounds \\
\hline Bacteria & 1 & 3 \\
\hline Fungi & 0 & 3 \\
\hline Mycorrhiza & 1 & 3 \\
\hline Bacterivores & 0 & 2 \\
\hline Fungivores & 0 & 2 \\
\hline Detritivores & 0 & 0.5 \\
\hline Engineers & 0 & 0.5 \\
\hline Herbivores & 0 & 0.5 \\
\hline Predators & 0 & 0.5 \\
\hline
\end{tabular}

1 


\section{Table 4 (on next page)}

Averages \pm standard deviation from the sample of $100 \mathrm{~g}_{\max }$ vectors from the posterior distribution of the KEYLINK model calibrated for the Brasschaat Scots pine forest. 


\begin{tabular}{|l|l|}
\multicolumn{2}{|c}{ Sample g $\max$} \\
\hline Bacteria & $1.970 \pm 0.424$ \\
\hline Fungi & $0.295 \pm 0.134$ \\
\hline Mycorrhiza & $2.208 \pm 0.302$ \\
\hline Bacterivores & $0.205 \pm 0.098$ \\
\hline Fungivores & $0.095 \pm 0.050$ \\
\hline Detritivores & $0.091 \pm 0.050$ \\
\hline Engineers & $0.292 \pm 0.062$ \\
\hline Herbivores & $0.028 \pm 0.018$ \\
\hline Predators & $0.408 \pm 0.060$ \\
\hline
\end{tabular}

1 


\section{Table 5 (on next page)}

Effect of changes in input parameters on the average $\mathrm{C}$ pool (in $\mathrm{g} \mathrm{C}^{-3}$ ) size over 10 years.

Averages from 100 runs of ten years with $g_{\max }$ parameter sets of the sample from the posterior distribution. The "basal" column has the results using reference input parameters (Supplemental File S2), and the other columns show the results with lower litter recalcitrance (rec $20 \%$ ), lower input litter $\mathrm{C}: \mathrm{N}$ ratio $\left(\mathrm{C}: \mathrm{N}_{\text {iti }} 40\right)$, higher $\mathrm{pH}(5.9)$, excluding predators $\left(\mathrm{B}_{\text {pred }} 0\right)$ and a higher clay content in the soil (clay $\left.15 \%\right)$, respectively. 


\begin{tabular}{|c|c|c|c|c|c|c|}
\hline C pools & basal & rec $20 \%$ & $\mathrm{CN}_{\text {lit }} 40$ & pH 5.9 & $\mathbf{B}_{\text {pred }} \mathbf{0}$ & clay $15 \%$ \\
\hline Bacteria $\left(\mathrm{g} \mathrm{C} / \mathrm{m}^{3}\right)$ & 5,98 & 6,94 & 6,35 & 5,90 & 2,67 & 4,75 \\
\hline Fungi $\left(\mathrm{g} \mathrm{C}^{2} \mathrm{~m}^{3}\right)$ & 210,14 & 224,83 & 231,33 & 158,06 & 30,70 & 141,83 \\
\hline Mycorrhiza $\left(\mathrm{g} \mathrm{C} / \mathrm{m}^{3}\right)$ & 39,83 & 40,20 & 40,03 & 38,70 & 29,75 & 39,27 \\
\hline Bacterivores $\left(\mathrm{g} \mathrm{C} / \mathrm{m}^{3}\right)$ & 0,00 & 0,00 & 0,00 & 0,00 & 0,03 & 0,00 \\
\hline Fungivores $\left(\mathrm{g} \mathrm{C} / \mathrm{m}^{3}\right)$ & 0,30 & 0,31 & 0,39 & 0,18 & 0,90 & 0,40 \\
\hline Detritivores $\left(\mathrm{g} \mathrm{C} / \mathrm{m}^{3}\right)$ & 2,49 & 2,12 & 2,01 & 3,83 & 145,39 & 0,87 \\
\hline Engineers $\left(\mathrm{g} \mathrm{C}^{2} \mathrm{~m}^{3}\right)$ & 0,04 & 0,04 & 0,04 & 0,51 & 1,54 & 0,05 \\
\hline Herbivores $\left(\mathrm{g} \mathrm{C} / \mathrm{m}^{3}\right)$ & 0,12 & 0,12 & 0,13 & 0,02 & 5,48 & 0,16 \\
\hline Predators $\left(\mathrm{g} \mathrm{C}^{2} \mathrm{~m}^{3}\right)$ & 3,33 & 2,86 & 2,87 & 6,41 & 0,00 & 1,36 \\
\hline Litter $\left(\mathrm{g} \mathrm{C} / \mathrm{m}^{3}\right)$ & 3695,08 & 3262,71 & 3481,79 & 3728,85 & 2727,81 & 4245,54 \\
\hline $\operatorname{SOM}\left(\mathrm{g} \mathrm{C} / \mathrm{m}^{3}\right)$ & 10825,04 & 10941,01 & 10742,97 & 9347,23 & 3175,08 & 11655,70 \\
\hline
\end{tabular}

1 


\section{Table 6(on next page)}

Effect of changes in input parameters on the posterior distribution of $\mathrm{C}$ pool (in $\mathrm{g} \mathrm{C}^{-3}$ ) size over 10 years.

Minimum and maximum values within 100 runs of ten years with $g_{\max }$ parameter sets of the sample from the posterior distribution. The "basal" columns have the results using reference input parameters (Supplemental File S2), and the following columns show the same changes from basal as in Table 5. For $\mathrm{C}$ pool notation see Table $\mathbf{2}$. 


\begin{tabular}{|c|c|c|c|c|c|c|c|c|c|c|c|c|}
\hline \multirow{2}{*}{$\begin{array}{l}\text { C } \\
\text { pools } \\
(\mathrm{g} \\
\left.\mathrm{C} / \mathrm{m}^{3}\right)\end{array}$} & \multicolumn{2}{|c|}{ basal } & \multicolumn{2}{|c|}{ rec $20 \%$} & \multicolumn{2}{|c|}{$\mathrm{CN}_{\text {lit }} 40$} & \multicolumn{2}{|c|}{ pH 5.9} & \multicolumn{2}{|c|}{$B_{\text {pred }} 0$} & \multicolumn{2}{|c|}{ clay $15 \%$} \\
\hline & $\min$ & $\max$ & $\min$ & $\max$ & $\min$ & $\max$ & $\min$ & $\max$ & $\min$ & $\max$ & $\min$ & $\max$ \\
\hline $\mathbf{B}_{\mathrm{b}}$ & $\begin{array}{r}9,61 \mathrm{E}- \\
42\end{array}$ & 670,64 & $\begin{array}{r}3,41 \mathrm{E}- \\
43\end{array}$ & 676,40 & $\begin{array}{r}8,48 \mathrm{E}- \\
38\end{array}$ & 683,87 & 0,00 & 669,74 & 0,00 & 547,97 & $\begin{array}{r}8,06 \mathrm{E}- \\
43\end{array}$ & 788,31 \\
\hline $\mathbf{B}_{\mathrm{f}}$ & $\begin{array}{r}2,63 \mathrm{E}- \\
25\end{array}$ & 4660,93 & $\begin{array}{r}3,87 \mathrm{E}- \\
25\end{array}$ & 4587,16 & $\begin{array}{r}3,74 \mathrm{E}- \\
25\end{array}$ & 4677,78 & 0,00 & 4656,39 & 0,00 & $\begin{array}{r}4038,0 \\
9\end{array}$ & $\begin{array}{r}2,56 \mathrm{E}- \\
25\end{array}$ & 4763,21 \\
\hline$B_{\text {myc }}$ & 4,18 & 649,45 & 5,11 & 684,88 & 5,79 & 652,73 & 0,00 & 648,45 & 0,00 & 592,13 & 5,87 & 515,60 \\
\hline B $_{\text {bvores }}$ & $\begin{array}{r}6,89 \mathrm{E}- \\
110\end{array}$ & 0,10 & $\begin{array}{r}4,91 \mathrm{E}- \\
105\end{array}$ & 0,10 & $\begin{array}{r}1,17 \mathrm{E}- \\
108\end{array}$ & 0,10 & 0,00 & 0,10 & 0,00 & 44,07 & $\begin{array}{r}1,13 \mathrm{E}- \\
96\end{array}$ & 0,10 \\
\hline $\mathbf{B}_{\text {fvores }}$ & $\begin{array}{r}4,47 \mathrm{E}- \\
84\end{array}$ & 194,08 & $\begin{array}{r}5,82 \mathrm{E}- \\
84\end{array}$ & 169,06 & $\begin{array}{r}5,28 \mathrm{E}- \\
83\end{array}$ & 204,50 & 0,00 & 141,68 & 0,00 & 351,94 & $\begin{array}{r}1,27 \mathrm{E}- \\
74\end{array}$ & 244,39 \\
\hline $\mathbf{B}_{\text {det }}$ & $\begin{array}{r}1,13 \mathrm{E}- \\
67\end{array}$ & 1720,93 & $\begin{array}{r}3,76 \mathrm{E}- \\
67\end{array}$ & 1524,58 & $\begin{array}{r}3,02 \mathrm{E}- \\
68\end{array}$ & 1567,73 & 0,00 & 6898,50 & 0,00 & $\begin{array}{r}5997,9 \\
0\end{array}$ & $\begin{array}{r}7,56 \mathrm{E}- \\
79\end{array}$ & 431,85 \\
\hline$B_{\text {eng }}$ & $\begin{array}{r}7,13 \mathrm{E}- \\
178\end{array}$ & 61,50 & $\begin{array}{r}6,54 \mathrm{E}- \\
176\end{array}$ & 33,87 & $\begin{array}{r}5,45 \mathrm{E}- \\
172\end{array}$ & 74,46 & 0,00 & 396,62 & 0,00 & 88,62 & $\begin{array}{r}7,18 \mathrm{E}- \\
140\end{array}$ & 43,86 \\
\hline B $_{\text {hvores }}$ & $\begin{array}{r}1,11 \mathrm{E}- \\
68\end{array}$ & 49,65 & $\begin{array}{r}5,23 \mathrm{E}- \\
65\end{array}$ & 49,75 & $\begin{array}{r}1,78 \mathrm{E}- \\
65\end{array}$ & 49,64 & $\begin{array}{r}3,78 \mathrm{E}- \\
89\end{array}$ & 34,32 & $\begin{array}{r}7,95 \mathrm{E}- \\
22\end{array}$ & 85,00 & $\begin{array}{r}1,12 \mathrm{E}- \\
56\end{array}$ & 51,33 \\
\hline B $_{\text {pred }}$ & $\begin{array}{r}4,72 \mathrm{E}- \\
21\end{array}$ & 1616,28 & $\begin{array}{r}4,73 \mathrm{E}- \\
21\end{array}$ & 1409,80 & $\begin{array}{r}4,72 \mathrm{E}- \\
21\end{array}$ & 1466,09 & 0,00 & 5512,93 & 0,00 & 0,28 & $\begin{array}{r}4,60 \mathrm{E}- \\
21\end{array}$ & 452,07 \\
\hline Litter & $6,0 \mathrm{E}+01$ & 9056,63 & 42,89 & 8850,72 & 53,95 & 8996,91 & 60,08 & 8749,61 & 63,63 & $\begin{array}{r}7409,2 \\
8\end{array}$ & 75,00 & 9257,38 \\
\hline SOM & $2,35 \mathrm{E}+3$ & 15687,9 & 2356,64 & 16027,4 & 2350,89 & 15751,5 & 921,46 & 15687,4 & 1340,6 & 11589 & 3919,25 & 15842,3 \\
\hline
\end{tabular}




\section{Table 7 (on next page)}

Effect of changes in input parameter on major output fluxes over 10 years.

The first three rows show bacterial, fungal and mycorrhiza respiration (R) fluxes $\left(\mathrm{g} \mathrm{C} \mathrm{m}^{-3}\right)$, respectively. The next three rows show the total turnover $\left(\mathrm{g} \mathrm{C}^{-3}\right)$ on an organic matter pool carried out by bacteria (Bact) or engineers (Eng) over 10 years. The penultimate row shows the fungi to bacteria ratio. And the last row is soil water content $\left(S W C, I \mathrm{~m}^{-3}\right)$. Columns show average values and standard deviations from 100 runs of ten years from the sample of the posterior distribution, with a basal scenario using reference input parameters (Supplemental File S2), and the same changes from it as in Table 5. 


\begin{tabular}{|l|l|c|c|c|c|c|c|}
\hline & units & basal & rec $20 \%$ & $\mathbf{C}_{\text {lit }} \mathbf{4 0}$ & pH 5.9 & \multicolumn{1}{c|}{ B $_{\text {pred }}$ 0 } \\
\hline $\mathbf{R}_{\text {bact }}$ & $\mathrm{g} \mathrm{C} \mathrm{m}^{-3}$ & $250.2 \pm 222.8$ & $293.6 \pm 227.2$ & $262.3 \pm 225.7$ & $248.9 \pm 222.4$ & $119.3 \pm 149.9$ & $204.5 \pm 225.9$ \\
\hline $\mathbf{R}_{\text {fun }}$ & $\mathrm{g} \mathrm{C} \mathrm{m}^{-3}$ & $\begin{array}{c}3924.8 \pm 5043 . \\
6\end{array}$ & $4190.0 \pm 5035.6$ & $4215.4 \pm 5166.1$ & $\begin{array}{c}3400.6 \pm 4776 . \\
3\end{array}$ & $\begin{array}{c}963.6 \pm 2669 . \\
4\end{array}$ & $\begin{array}{c}2638.5 \pm 4270 \\
.7\end{array}$ \\
\hline $\mathbf{R}_{\text {myc }}$ & $\mathrm{g} \mathrm{C} \mathrm{m}^{-3}$ & $773.9 \pm 443.7$ & $785.3 \pm 447.3$ & $779.1 \pm 445.9$ & $760.4 \pm 431.3$ & $560.3 \pm 335.5$ & $760.5 \pm 447.5$ \\
\hline $\begin{array}{l}\text { Bact SOM } \\
\text { turnover }\end{array}$ & $\mathrm{g} \mathrm{C} \mathrm{m}^{-3}$ & $995.6 \pm 758.2$ & $1100.2 \pm 716.3$ & $1036.5 \pm 757.7$ & $985.4 \pm 752.6$ & $438.6 \pm 524.2$ & $780.2 \pm 741.7$ \\
\hline $\begin{array}{l}\text { Bact litter } \\
\text { turnover }\end{array}$ & $\mathrm{g} \mathrm{C} \mathrm{m}^{-3}$ & $258.6 \pm 264.1$ & $367.7 \pm 328.6$ & $280.2 \pm 276.2$ & $257.6 \pm 263.9$ & $119.6 \pm 170.6$ & $223.5 \pm 279.7$ \\
\hline $\begin{array}{l}\text { Eng litter } \\
\text { turnover }\end{array}$ & $\mathrm{g} \mathrm{C} \mathrm{m}^{-3}$ & $1.5 \pm 5.3$ & $1.3 \pm 4.5$ & $1.3 \pm 4.4$ & $43.8 \pm 104.4$ & $97.3 \pm 72.1$ & $2.0 \pm 5.8$ \\
\hline $\mathbf{B}_{\text {fungi }} / \mathbf{B}_{\text {bact }}$ & - & 35.2 & 32.4 & 36.4 & 26.8 & 11.5 & 29.9 \\
\hline SWC & $1 \mathrm{~m}^{-3}$ & $147.9 \pm 32.7$ & $149.2 \pm 32.4$ & $150.3 \pm 33.7$ & $144.2 \pm 31.1$ & $134.2 \pm 21.8$ & $321.6 \pm 27.2$ \\
\hline
\end{tabular}


Figure 1

Simplified model scheme.

General structure of the KEYLINK model. Square boxes represent pools of organic matter. Wide double-line arrows, with a circle within the arrow, represent fluxes between pools (blue arrowheads show bidirectional fluxes). Isolated circles represent abiotic factors that affect model fluxes, and red narrow arrows connect each factor or pool with the model parts (at the arrowheads) that are regulated by them.

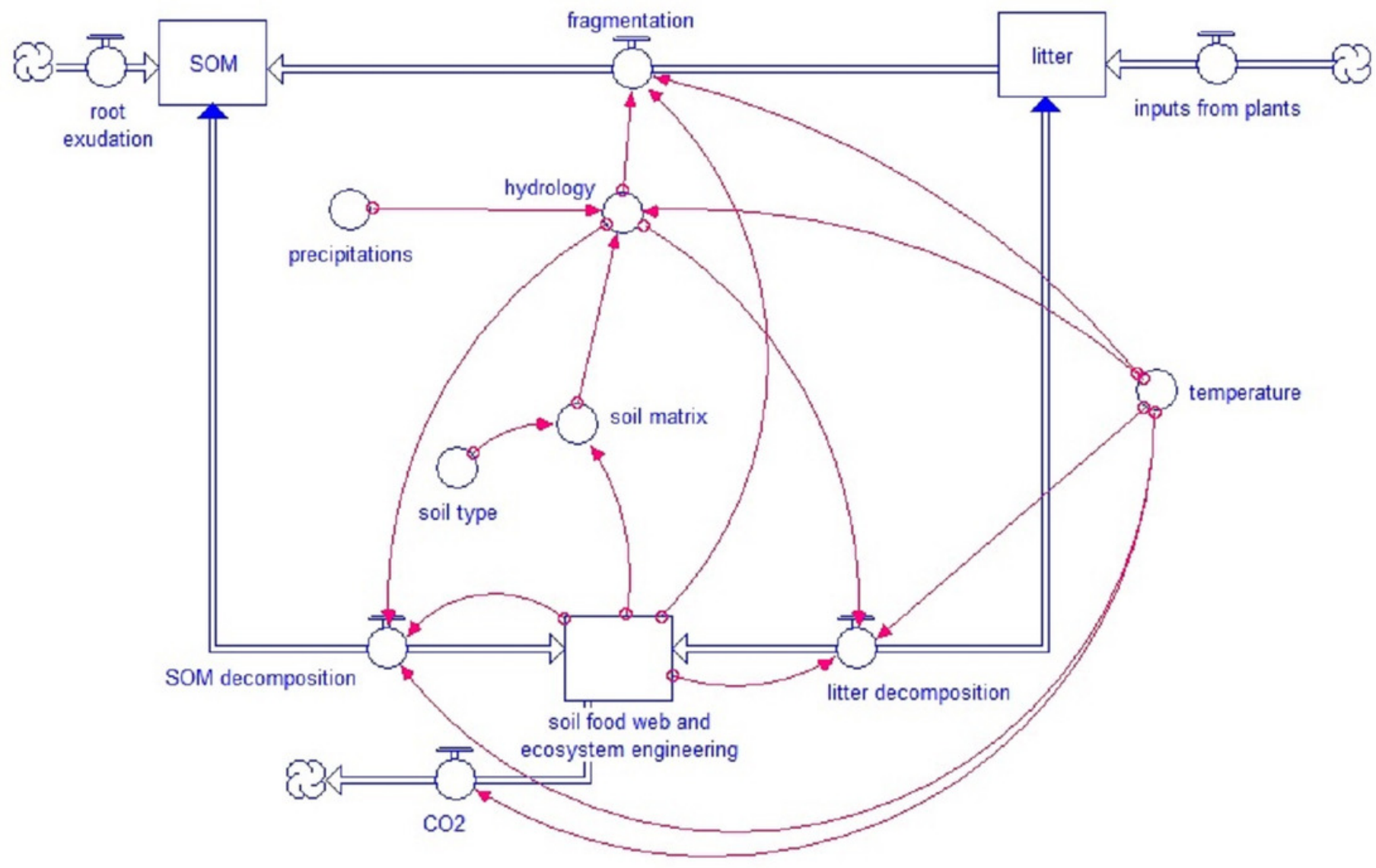


Figure 2

Pools and fluxes in the KEYLINK model.

Scheme of $\mathrm{C}$ pools with their interactions. All pools, soil, microorganisms and fauna (see

Table S1.2 in Supplemental File S1) are represented in the model in the same units ( $\mathrm{g} \mathrm{C}$ $\left.\mathrm{m}^{-3}\right)$. The arrows represent carbon fluxes between the pools; each arrow is represented by a term in the model equations.

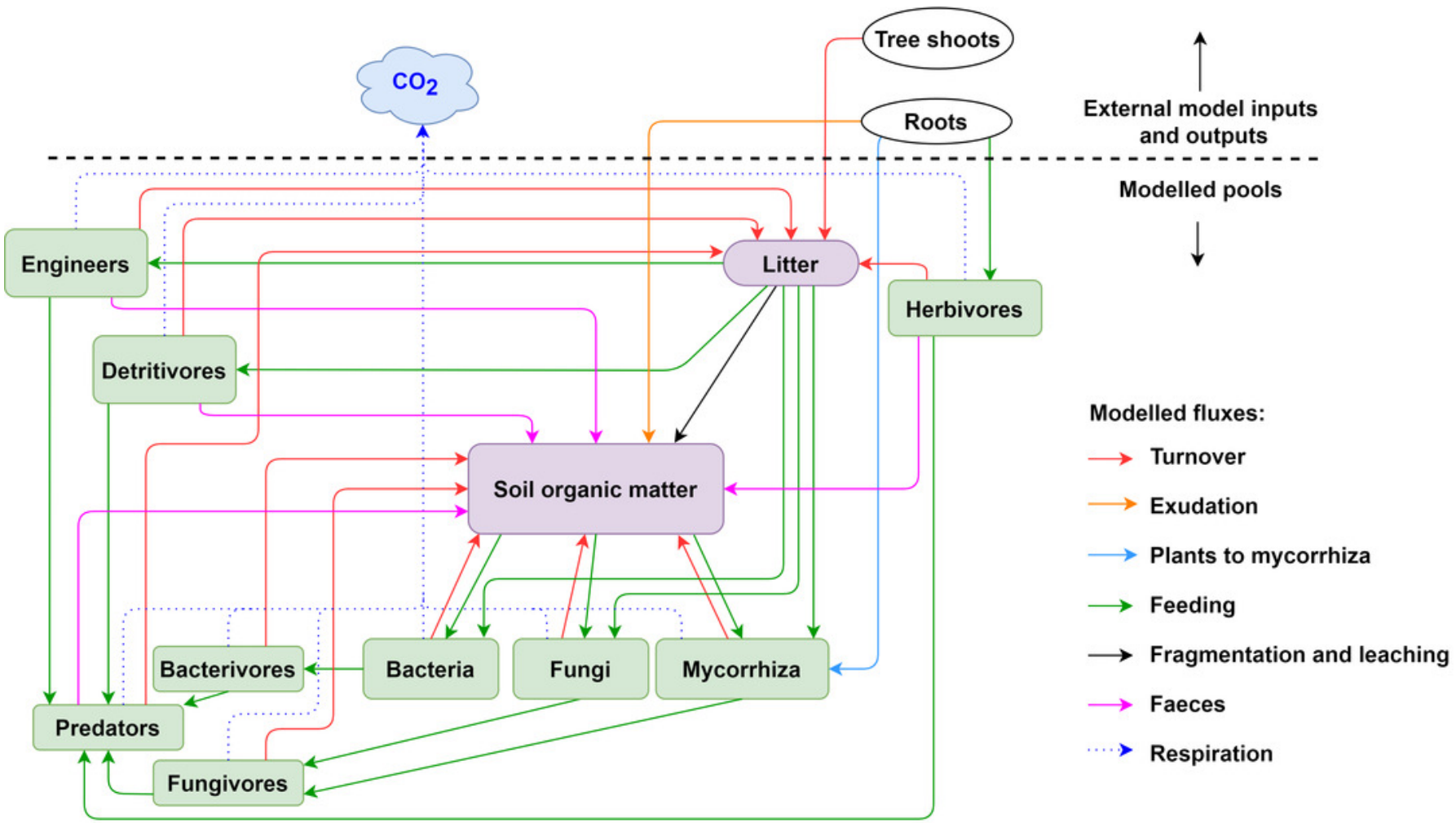




\section{Figure 3}

C pools daily biomass averages and standard deviations from the basal scenario

$\mathrm{C}$ pools (in $\mathrm{g} \mathrm{C}^{-3}$ ) averages (black) and standard deviations (grey) among 100 simulations of ten years using the $g_{\max }$ sample from the basal simulation scenario. A) bacteria pool; non-mycorrhizal fungi; C) mycorrhizal fungi; D) microbivores feeding on bacteria; E) microbivores feeding on fungi; F) non-engineer detritivores; G) ecosystem engineers; $\mathbf{H}$ ) herbivores; I) predators; J) plant litter; K) soil organic matter.
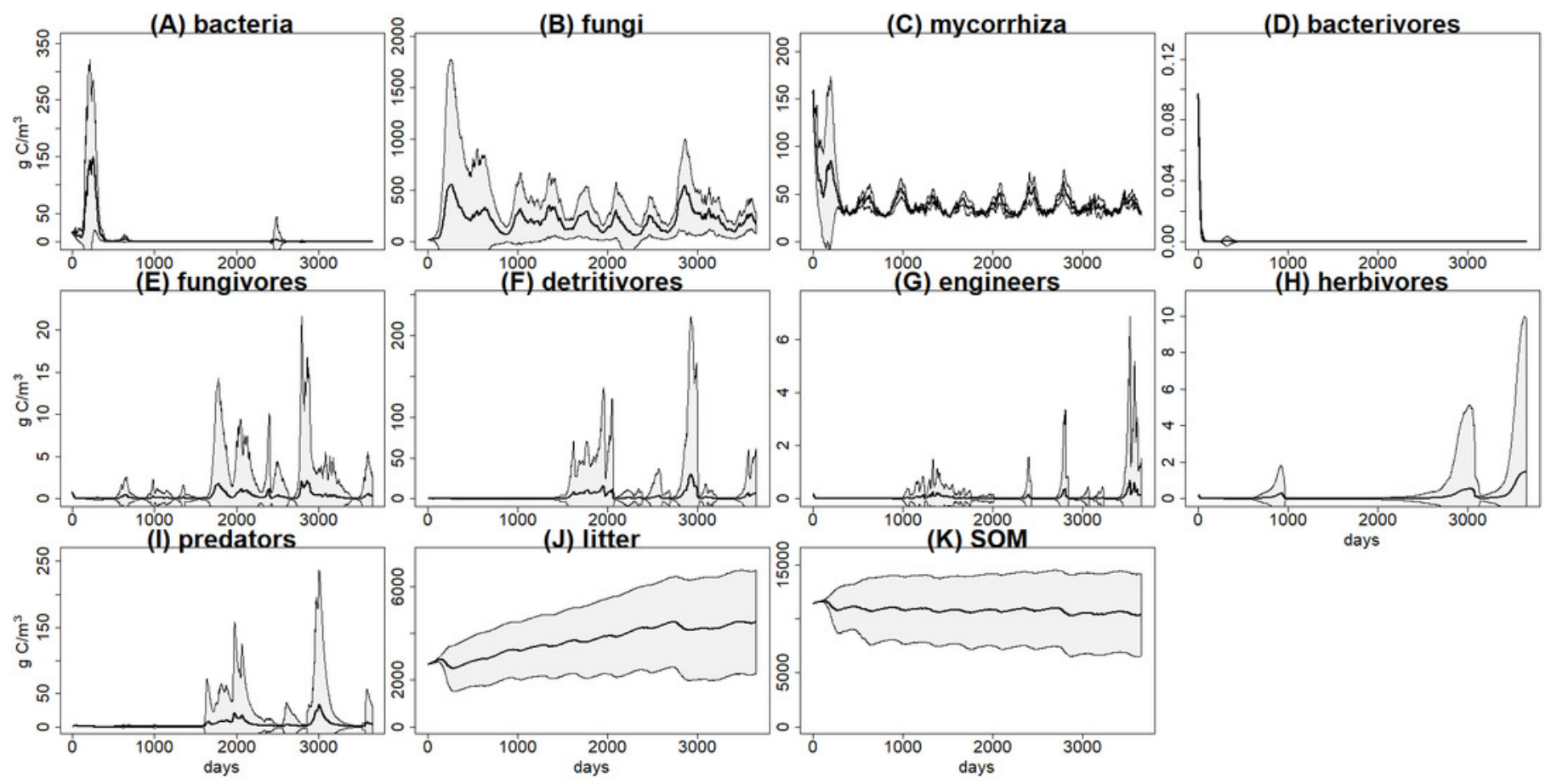


\section{Figure 4}

$\mathrm{C}$ pools daily biomass averages under different scenarios.

Averages of $\mathrm{C}$ pools (in $\mathrm{g} \mathrm{C}^{-3}$ ) among 100 simulations of ten years using the $\mathrm{g}_{\max }$ sample, with the basal simulation (black solid lines), and the alternative scenarios: higher clay content (red dashed lines), lower input litter C:N (yellow dotted lines), excluding predators (dark blue dotted dashed lines), higher soil pH (green long dash lines) and lower litter recalcitrance (light blue, lines with two different dashes). Pools are the same as in Figure 3, i.e. the nine food web functional groups, litter and soil organic matter (SOM).
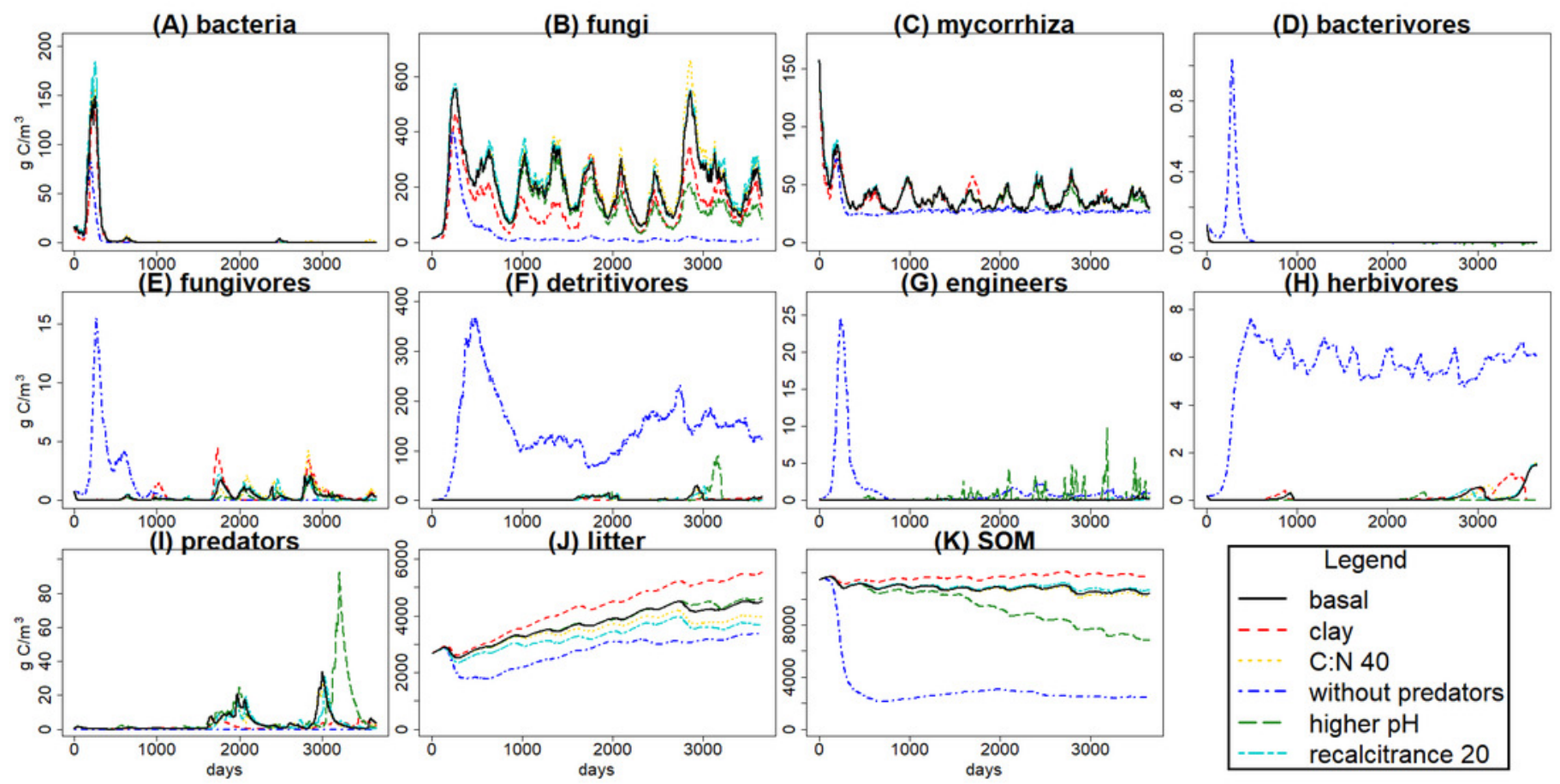
Figure 5

Daily volume averages of soil water content (SWC) and pore size classes in the soil matrix.

Means of volume (in $\mathrm{I} \mathrm{m}^{-3}$ ) among 100 simulations of ten years using the sample of $\mathrm{g}_{\max }$ vectors, for the evaluation scenarios (see Figure 4). Graphs A-D for pore size classes, E for SWC. The innaccesible pore size class is not shown because it was not affected by changes in porosity.
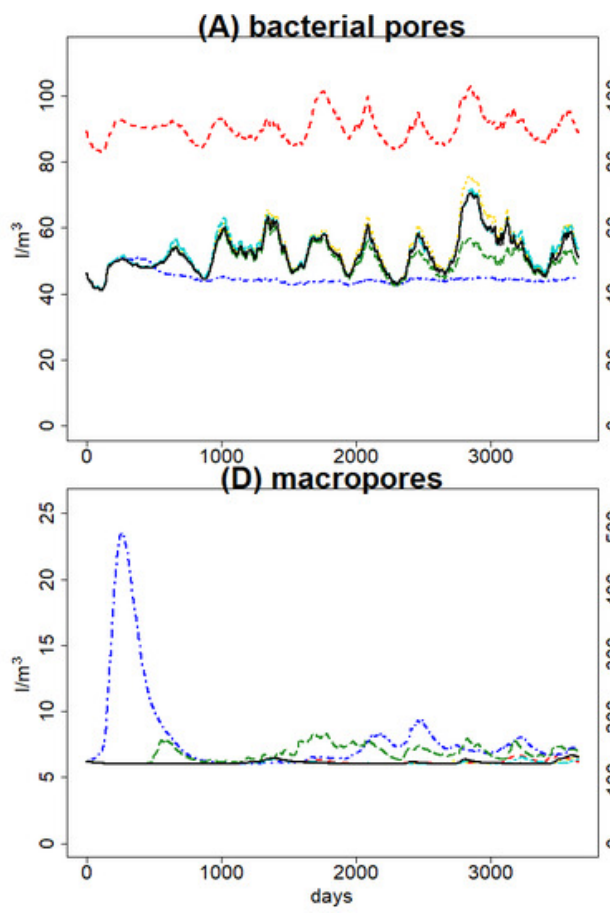

(B) micropores

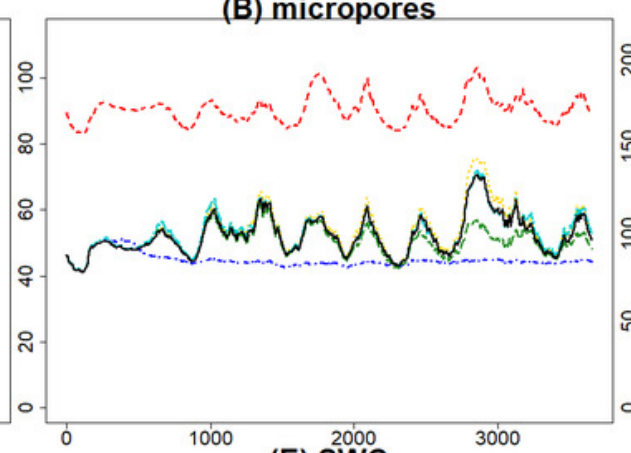

(E) SWC

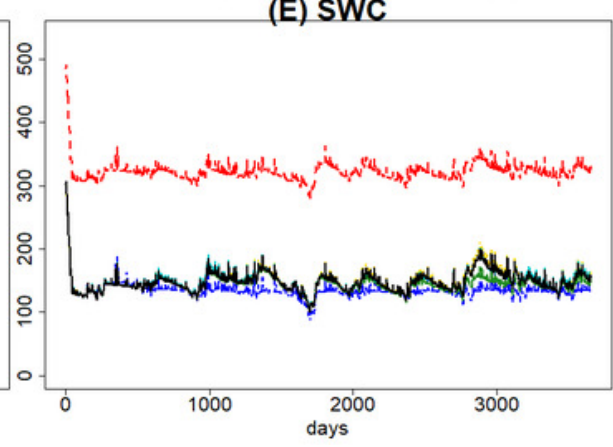

(C) mesopores

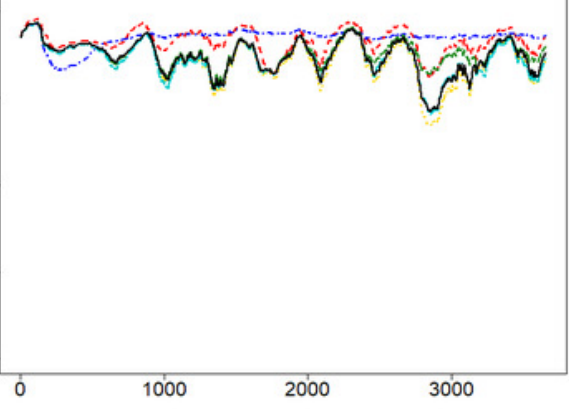

